\title{
العولمة وممارسة العمال حق الإضراب في الجزائر
}

\author{
Globalization and the exercise of workers the right to strike in Algeria \\ تاريخ الاستلام : 20181/05/30؛ تاريخ القبول : 2019/02/03
}
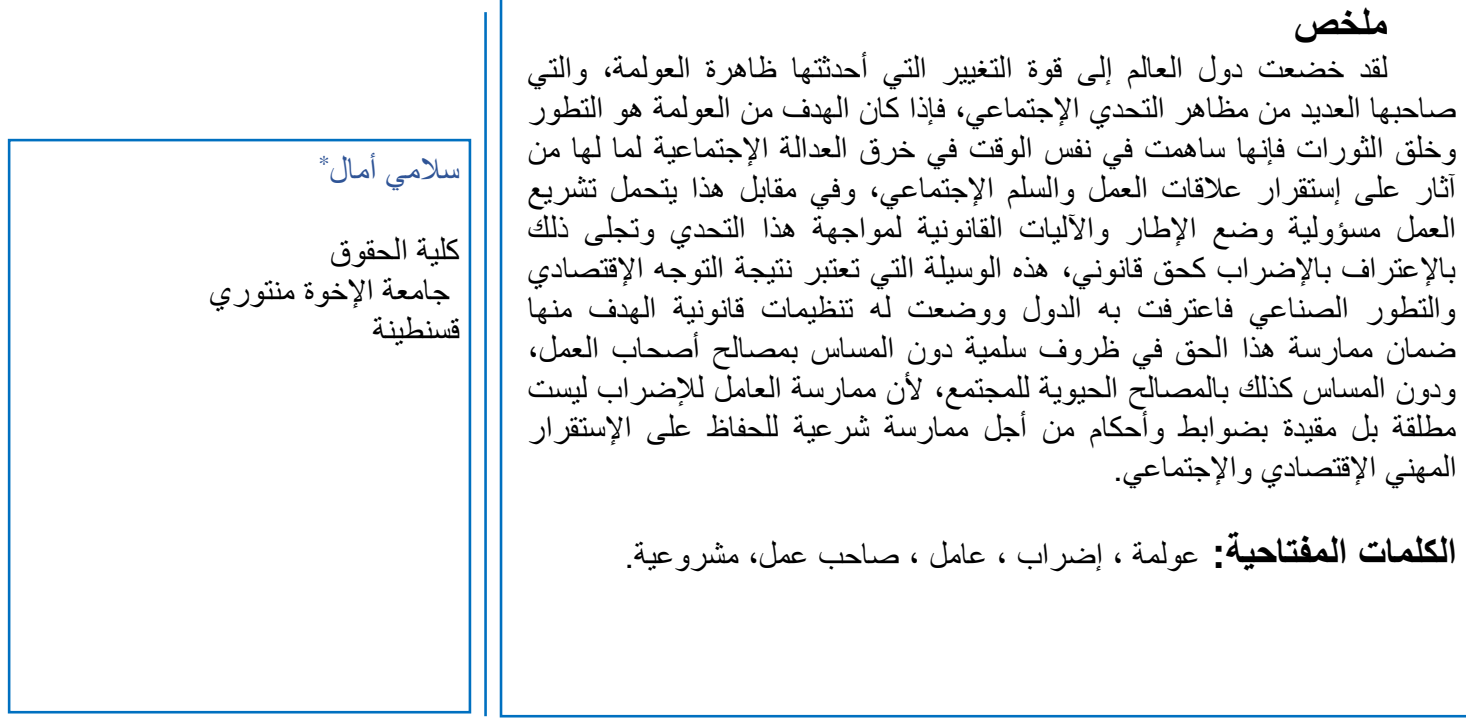

\section{Abstract}

The countries of the world have been subjected to the power of change brought about by the phenomenon of globalization, which is accompanied by many manifestations of social challenge. If globalization is aimed at the development and creation of revolutions, it contributes to the violation of social justice because of its effects on the stability of labor relations and social peace. Labor legislation is responsible for establishing the legal framework and mechanisms to meet this challenge. This is reflected in the recognition of the strike as a legal right. This method, which is the result of the economic orientation and industrial development, has been ognized by States and established legal regulations aimed at ensuring the exercise of this right under conditions of tuberculosis Without prejudice to the interests of employers and without prejudice to the vital interests of society, because the worker's strike is not absolute, but restricted by rules and regulations for the legitimate exercise of economic and social economic stability

Keywords: globalization, strike, worker, employer, legality.

\section{Résumé}

Les pays du monde ont été soumis au pouvoir de changement engendré par le phénomène de la mondialisation, accompagné de nombreuses manifestations de défis sociaux, si elle vise le développement et la création de révolutions, elle a contribué à la violation de la justice sociale en raison de ses effets sur la stabilité des relations de travail et la paix sociale, La législation du travail est chargée d'établir le cadre juridique et les mécanismes permettant de relever ce défi, comme en témoigne la reconnaissance de la grève comme un droit légitime. Cette méthode, fruit de l'orientation économique et du développement industriel, a été reconnue par les États et a mis en place des règles juridiques visant à assurer l'exercice de ce droit Sans préjudice des intérêts des employeurs, sans préjudice des intérêts vitaux de la société, car la pratique de grève du travailleur n'est pas absolue, mais limitée par les règles et réglementations permettant l'exercice légitime de la stabilité économique et sociale.

Mots-clés: mondialisation, grève, travailleur, employeur, légitime.

* Corresponding author, e-mail: ameeelsellami@gmail.com 
( I - I

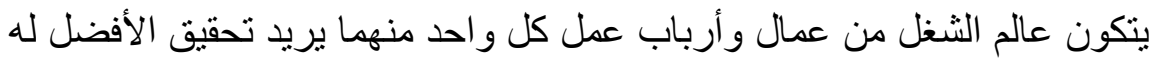

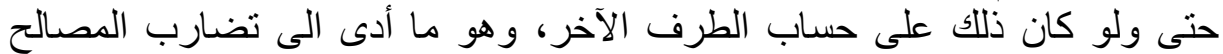

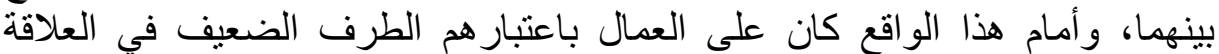

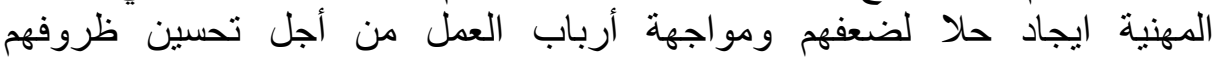

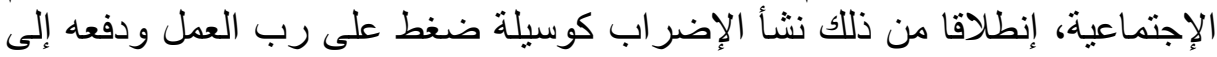

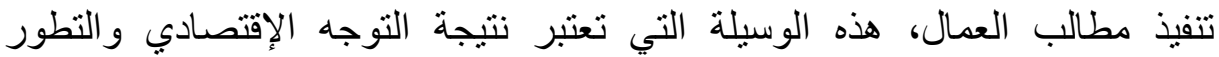

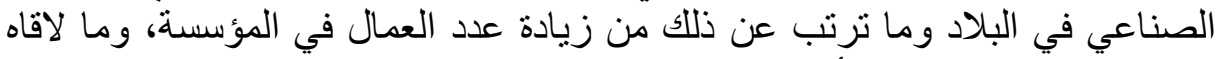

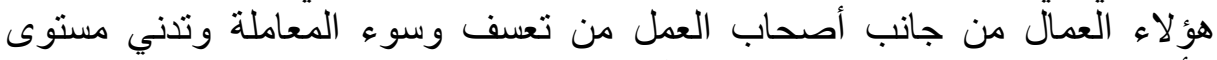
الأجور فضلا عن زيادة ساعات العمل وقسوة ظروفه، هذا كله لمواكبة التطورات

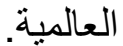

فكان للعولمة أثنار على الجانب الإجتماعي مست إستقرار العمالة، ذلك لأن إنان

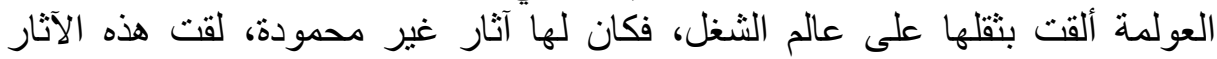

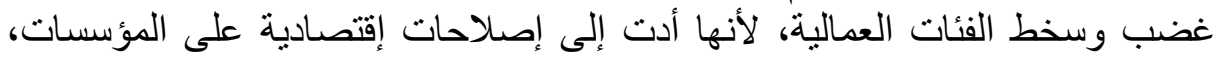

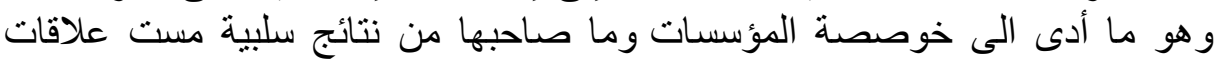

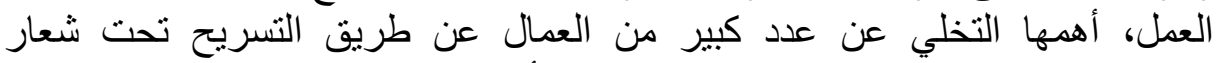

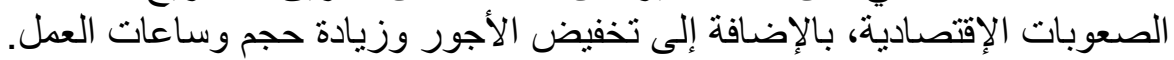

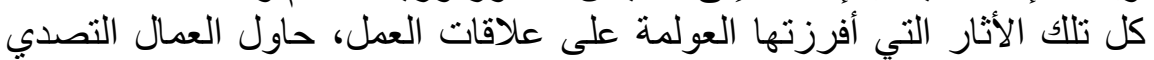

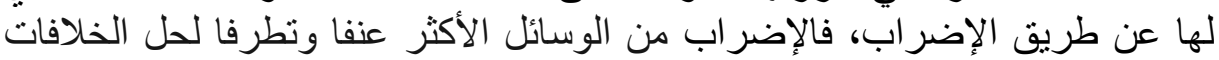

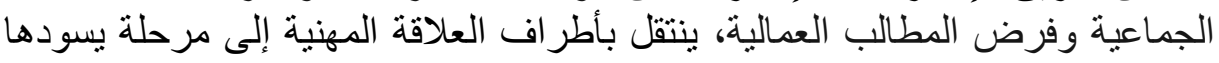

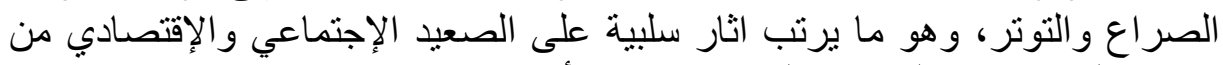

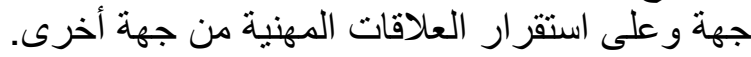

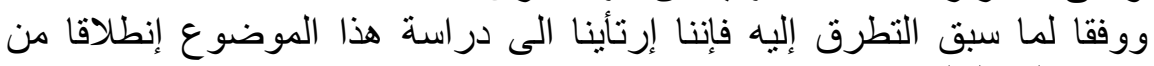

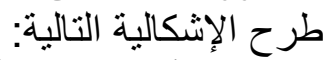

\section{كيف أثرت العولمة على ممالية مارسة العمال لحق الإضراب في الجزائر؟.}

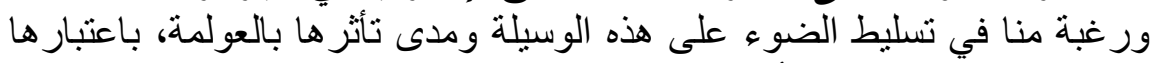

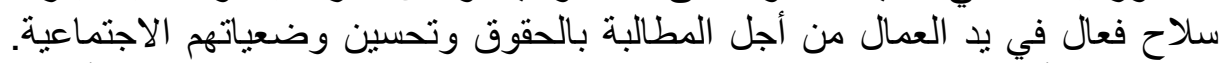

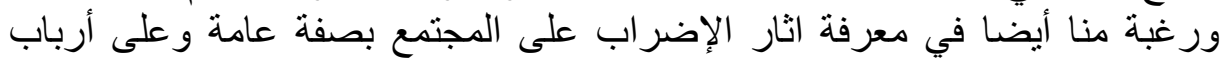

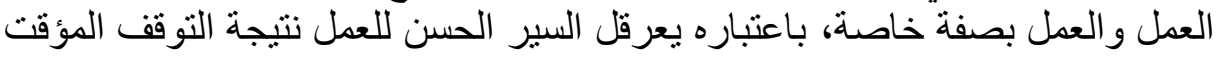

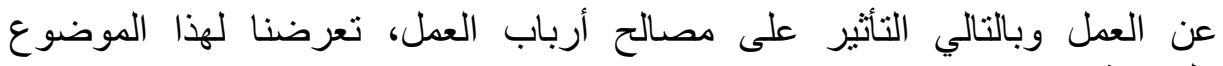
بالدر اسة.

والذي تكمن أهميته في كون الإضراب من بين أهم الحقوق العمالية المتأثرة

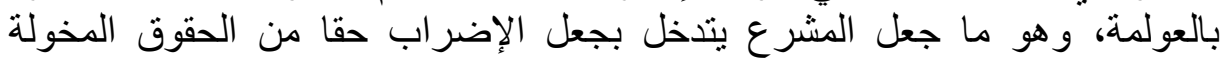

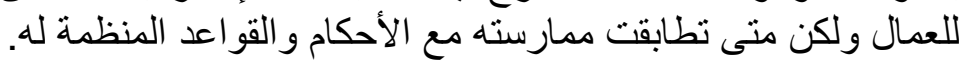

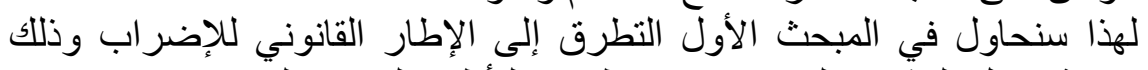

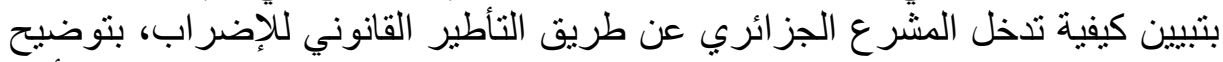

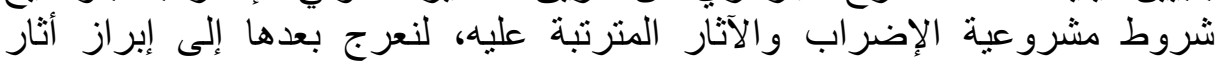

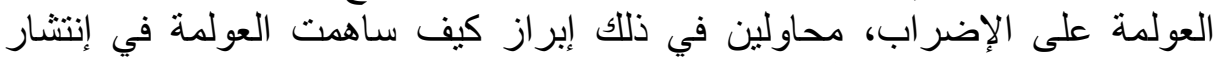
الحركات الإحتجاجية العمالية وفي نفس الوقت كيف فيف ساهمت في التضبيق من ممارسة

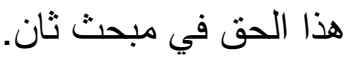

$$
\text { الــمبحث الأول: الإطار القانوني للإضراب. }
$$

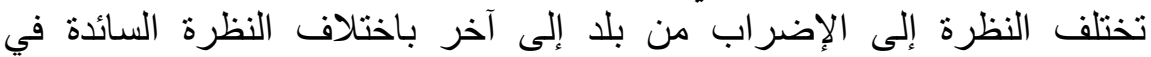
المجتمع، فأغلب التشريعات ترى أن الإضراب وسيلة للحصول على الحقوق 
المسلوبة(1)، وحق من الحقوق المعترف بها للعمال مكرس في مختلف الدساتير المعاصرة، ولهذا كان لا بد من تعريف الإضراب ومعرفة أساسه القانوني في

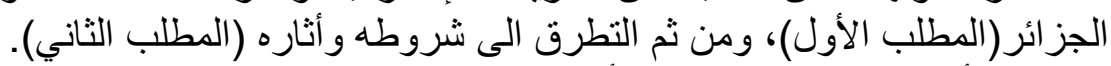

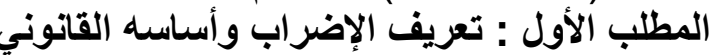

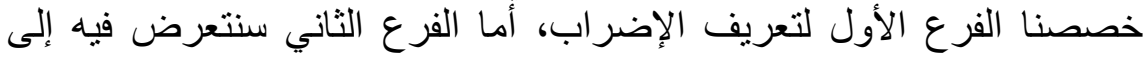
أساسـ القانوني.

\section{الفرع الأول : تعريف الإضراب.}

كلمة إضراب مأخوذة من اسم ساحة في باريس تسمى "GREVE"، أين كان

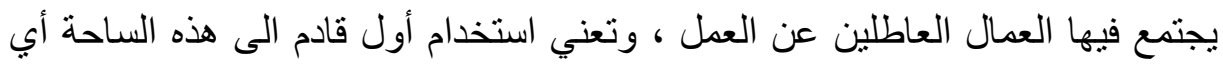

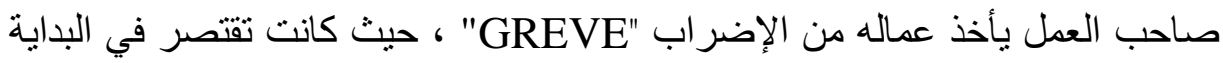
على منطقة باريس، وانتشر استعمالها في فرنسا كلها خلال القرن 19، هذا المفهوم

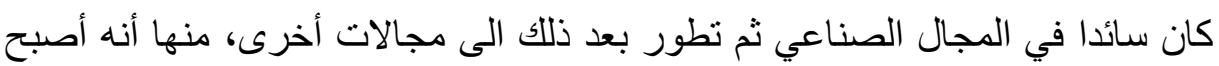
يعني خرقا للعادات و الأعر اف التي لها علاقة بمجال العمل(2)، هذا الخرف الذي بعتبات التبر

تحديا يهدف الى إربالك الساحة الإجتماعية(3).

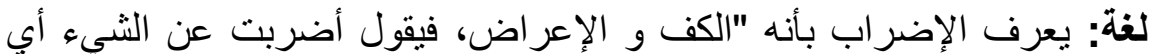

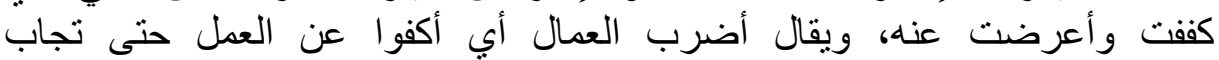
مطالبهم (4).

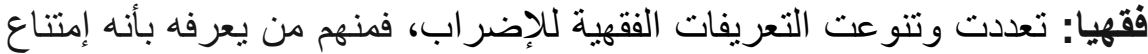

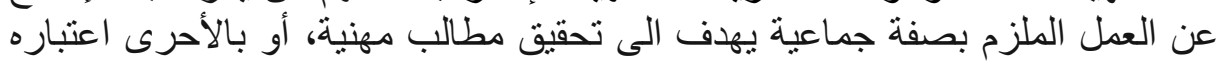

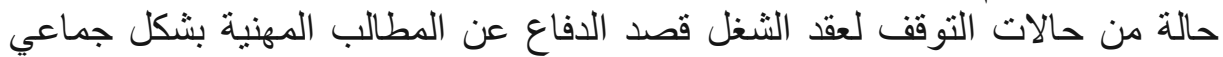

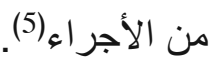

كما عرفه الدكتور و اضح رشيد بأنه امتتاع عن العمل لمدة محدودة يتمسك فيها

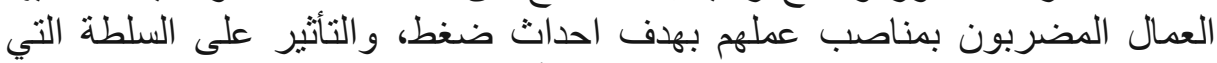

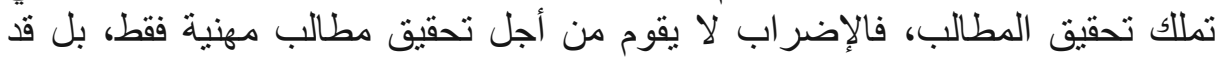
يقوم كذلك لإضهار التسخط أو التذمر للتعبيير عن الإحتجاج إزاء قضية سياسية أو تصنية اقتصادية أو اجتماعية(6) - (6)

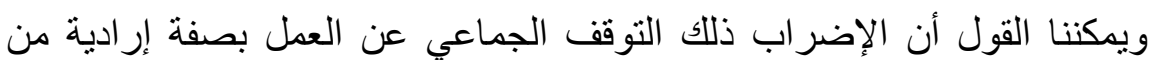

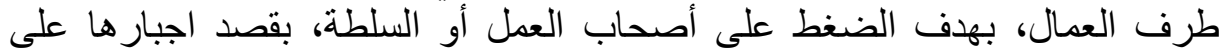
الخضوع لتلبية مطالبهم أو ايجاد حلول للنزاع القائم بينهم، فهو وسيلة للدفاع أو تدعيم التهاب

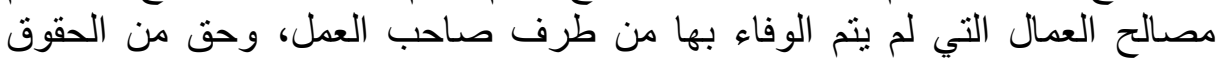
القانونية و الدستورية.

قانونيا لم يعتن المشرع الجزائري بتعريف الإضراب بموجب قانون 02/90

المعدل بالقانون 27/91 المتعلق بالوقاية من النزاعات الجماعية في العمل وتسويتها

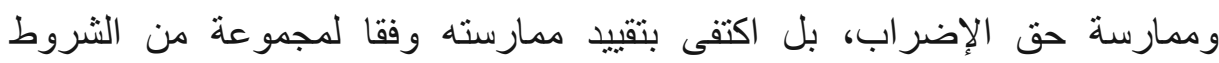
المنصوص عليها في القانون، موضحا الآثار المترنبة عن ممارسته.

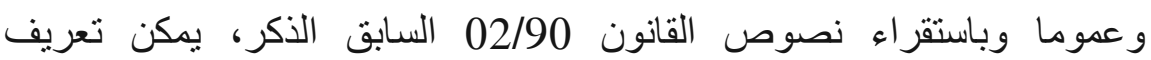

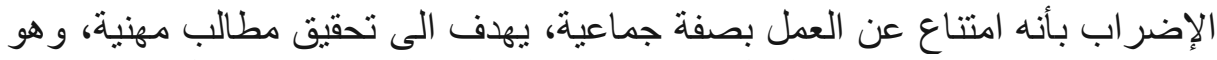

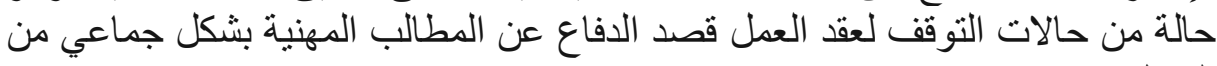




\section{الفرع الثاني: الأساس القانوني للإضراب.}

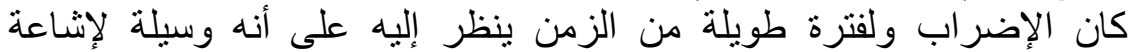

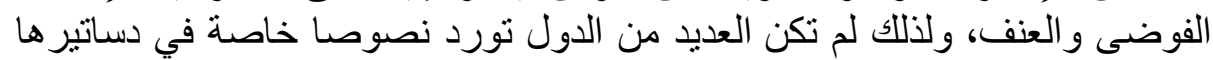

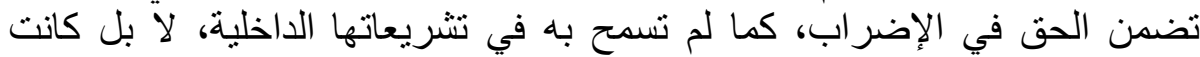

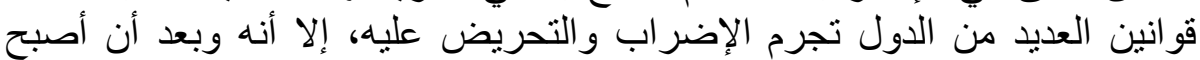

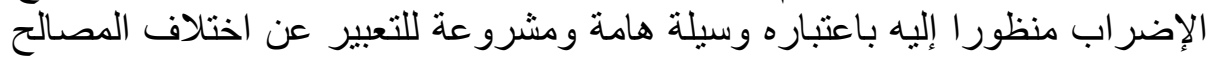

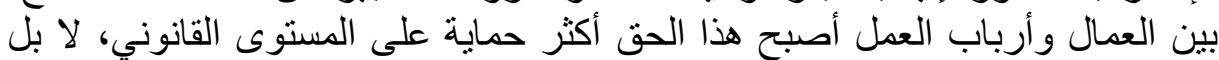

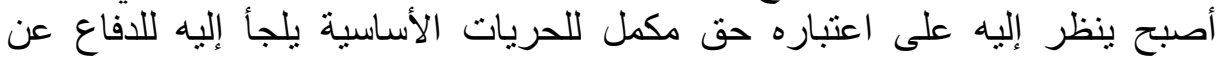

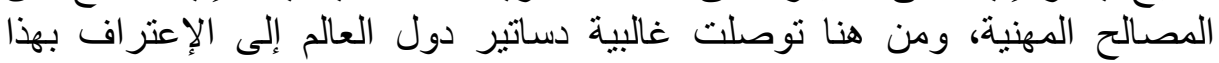

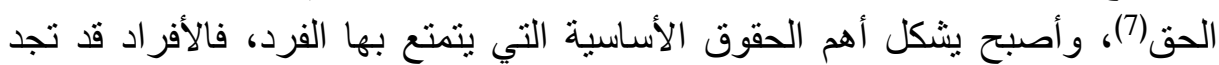

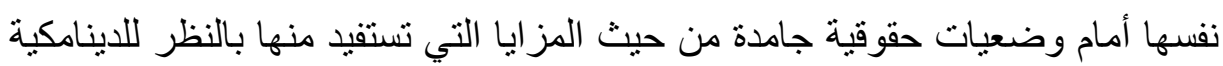

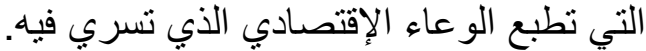
أول من اعنرف بالحق في الإضراب الإب كان الميثاق الإجتماعي الأوروبي في مادته

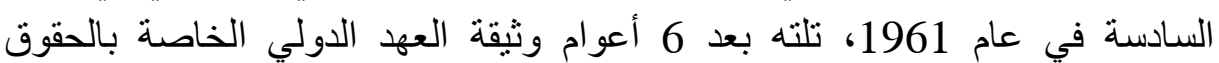

الإقتصادية والإجتماعية والثقافية في مادتها الثامنة. (8)

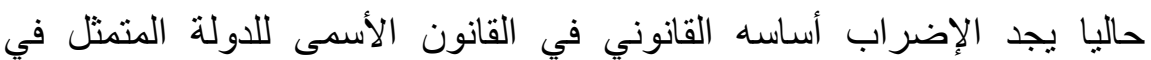

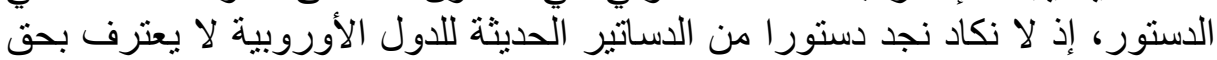

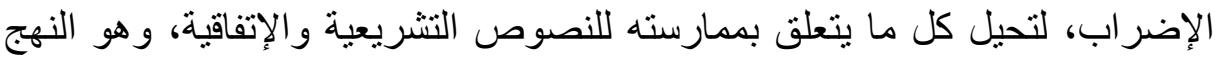
الذي سار عليه المشرع الجزائري، فقد كرسه دستور 1989 ثم دستور 1996 المعدل سنة 2016 في المادة 71 منه التي تتص على أنه:" الحق في الإضراب معترف به ويمارس في إطار القانون"، وأكده المشرع في قانون 11/90 المتعلق بعلاقات العمل، عندما نص في المادة 05 منه على أن اللجوء إلى الإضراب من الحقوق الأساسية التي لهوني

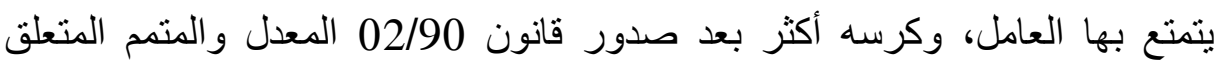

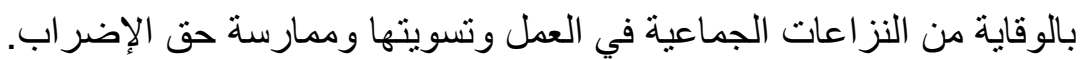

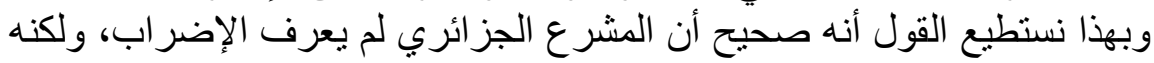

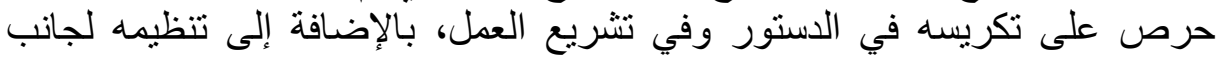

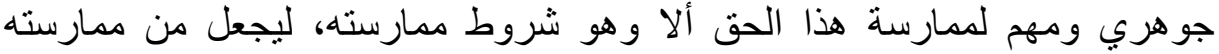
ممارسة مشرو عة ومثة.

الـمطلب الثاني: الإضراب بين المشرو الثروعية والعقاب.

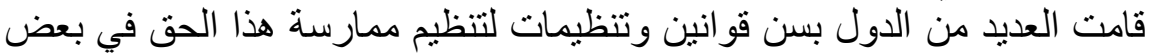
الأنشطة والقطاعات، وتحد منه في قطاعات أخرى، ومنعه في في مجال الأنشطة

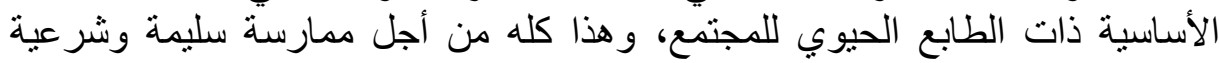
وحتى لا يكون هنالك تعسف في في إستعماله الأه

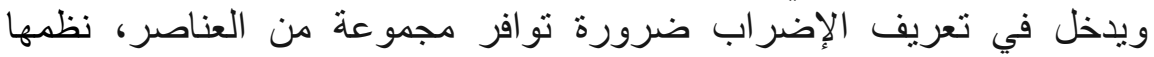

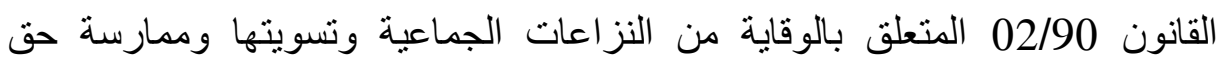

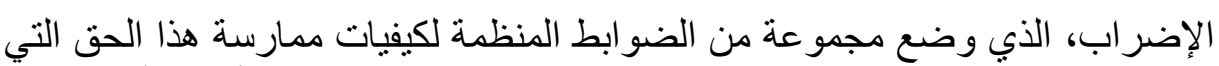

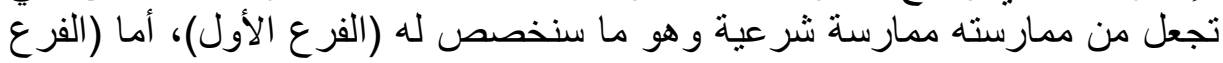
الثاني) فسنتطرق فيه إلى آثار الإضر ابته 


\section{الفرع الأول: مشروعية الإضراب.}

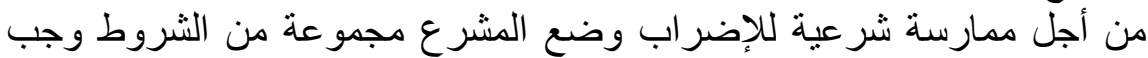

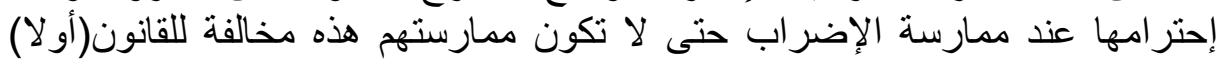
كما وضع حدودا لهذا الحق (ثانيا). أولا: شروط مشروعية الإضراب.

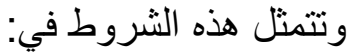

\section{1: إستكمال جميع طرق التسوية الودية.}

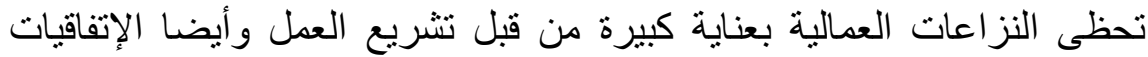

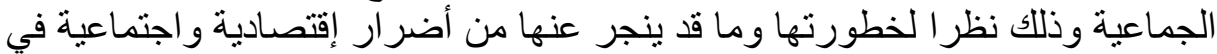

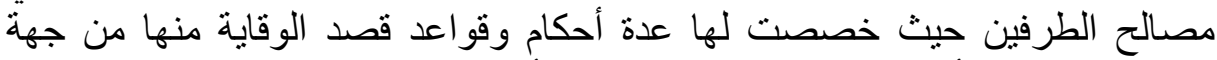

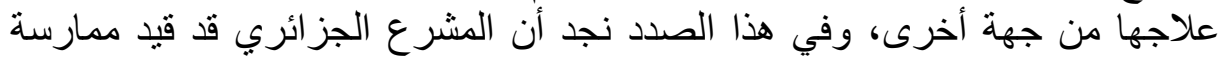
الإضر اب بشروط جد مشددة تتمثل في استنفاذ الطرق العلاجية لتسوية النزاع التهاع القائم،

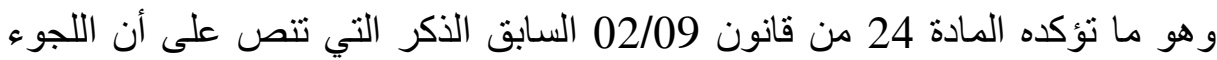

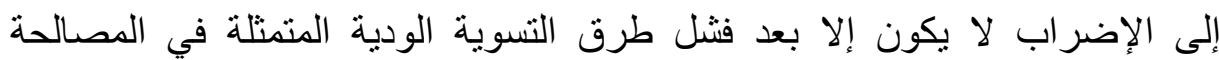

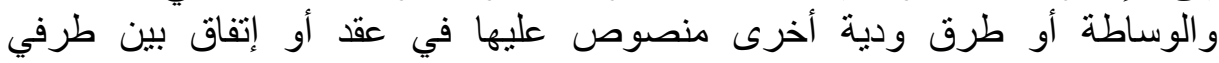

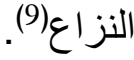

بالتالي مضمون هذا الثرط هو أنه لا يشرع في الإضر اب إلا بعد التأكد من فثل الثل

الوسائل الوقائية أو العلاجية الداخلية أو الخارجية(10).

2: صدور قرار الإضراب عن أغلبية العمال.

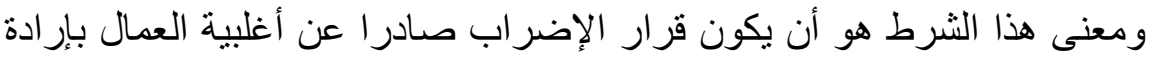
حرة دون اكر اه أو ضغط، فبالرجوع إلى المادة 28 من قانون

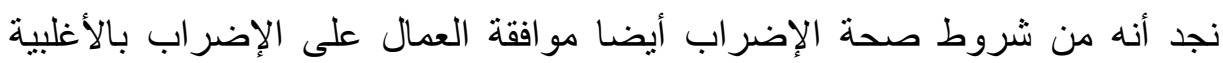

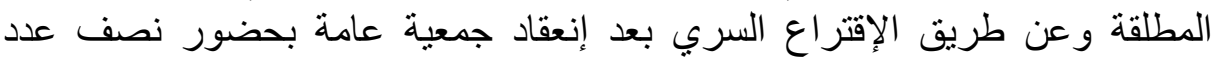

العمال المعنيين على الأقل(11).

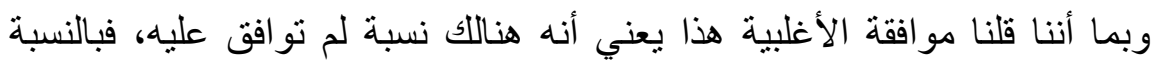

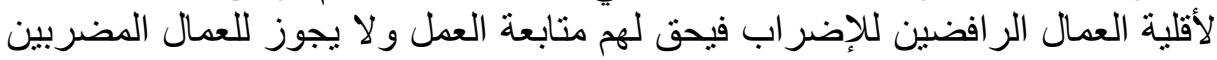

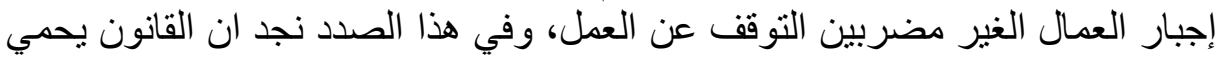

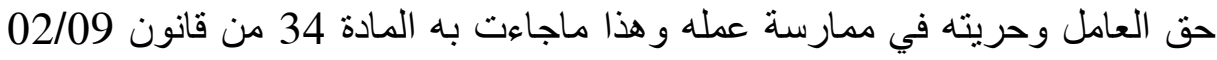

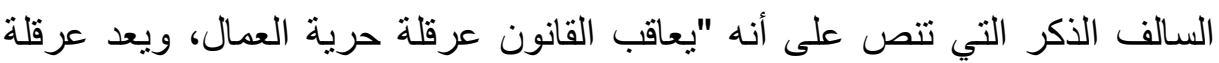

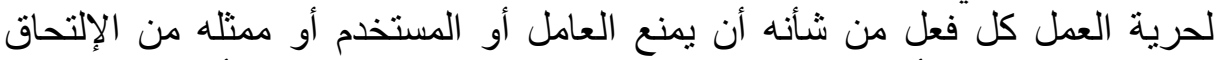

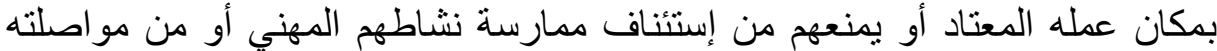
بالتهديد أو المناورة الإحتيالية أو العنف أو أو الإعتداء".

\section{3: أن يسبق الشروع في الإضراب منح صاحب العمل مهلة إخطار مسبقة.}

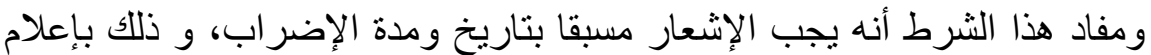

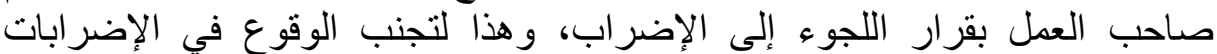

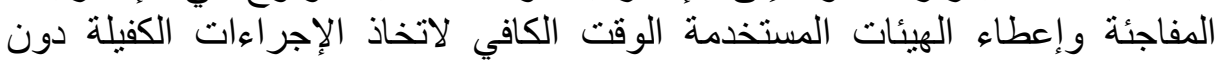

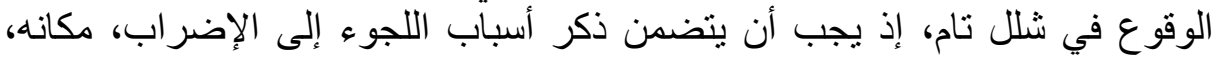

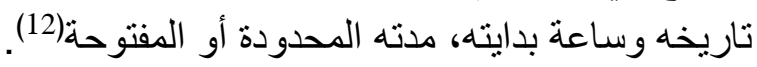

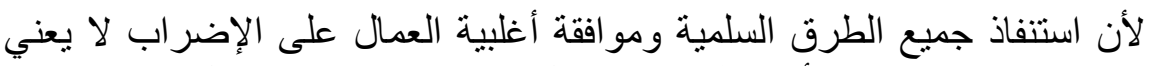
أن الاضراب شرعيا حيث ألزم القانون العمال بإخطار صاحب العة العمل مسبقا بقرار الإبرا 
الإضراب، ومنحه مهلة تبدأ من تاريخ صدور قرار الموافقة على الإضر اب الى تاريخ

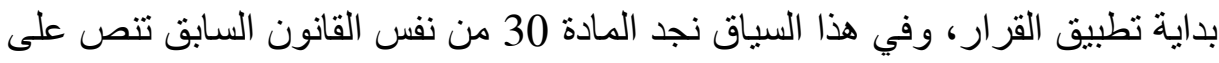
أنه :" تحسب مدة الاشعار المسبق بالإضراب ابتداء من تاريخ ايداعه لدى المستخدم و إعلام مفتشية العمل المختصة إقليميا.

تحدد هذه المدة عن طريق المفاوضة، و لا يمكن أن تقل عن ثمانية (08) أيام إبتداء من تاريخ ايداعه".

يتضح أن الهدف من إنتراط هذاءه المدة في الإخطار المسبق هي لعدم مفاجأة

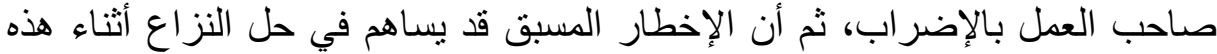

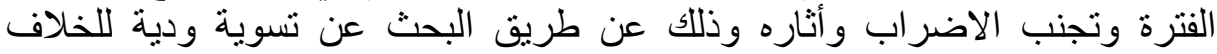

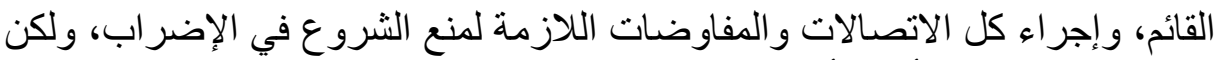

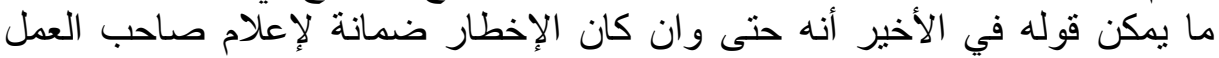

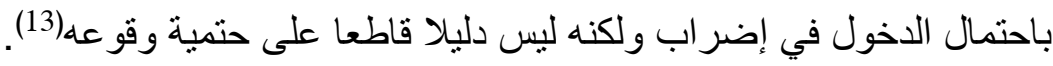
ثانيا: الحدود القانونية للإضراب.

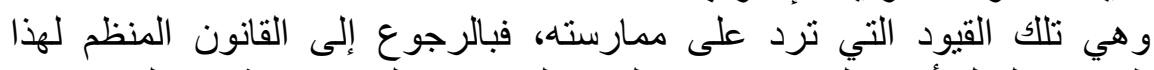

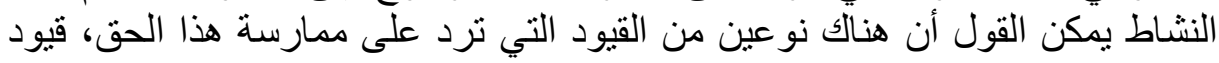

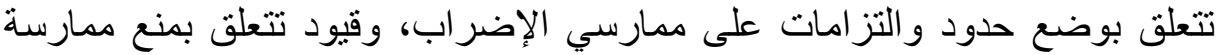
الإضر اب في القطاعات الإستر اتيجية والحيو الحية.

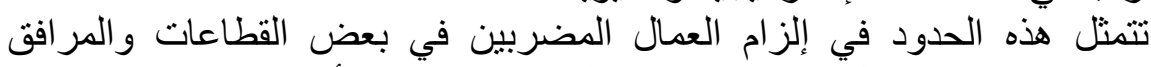

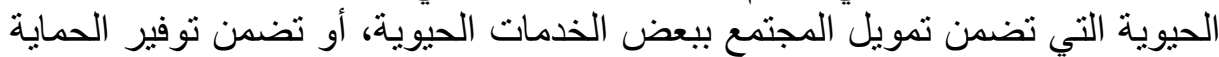
والأمن للأشخاص و الممنلكات أو التي لها علاقة مباشرة أو تأثثر مباثر بالثة بالمواطنين،

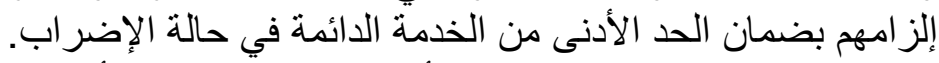

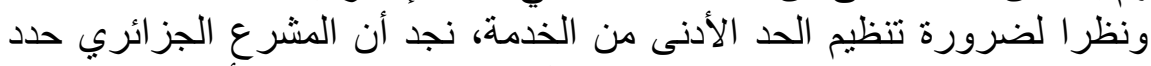

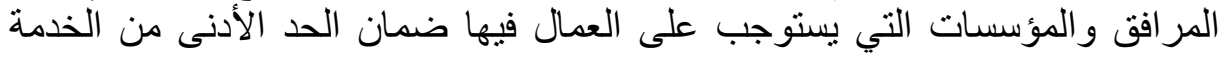

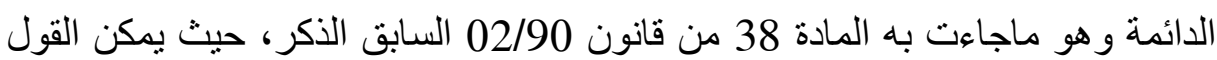

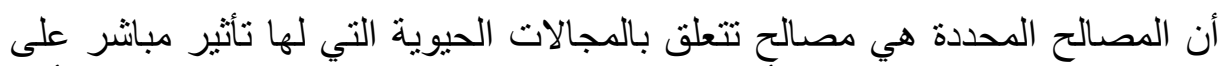

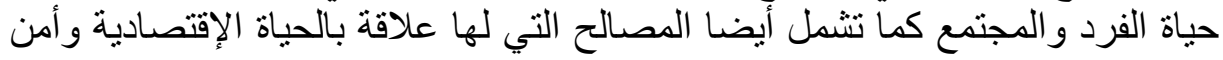

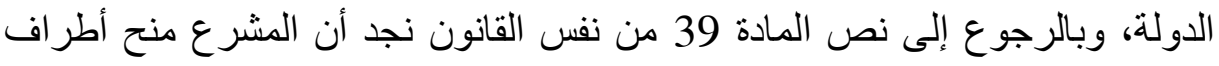

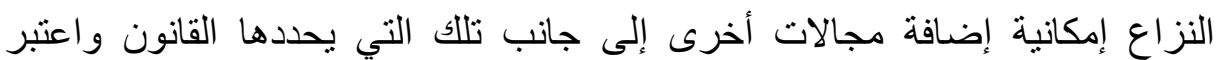

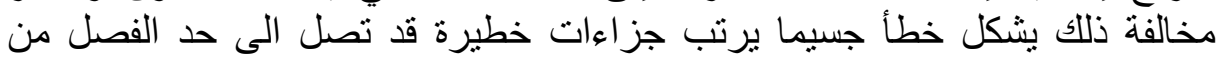

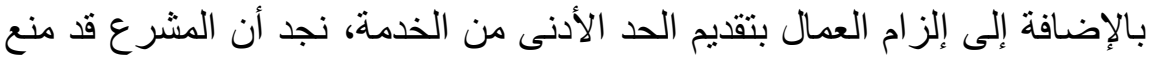

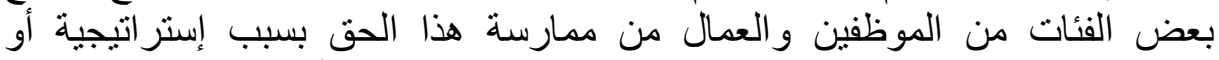

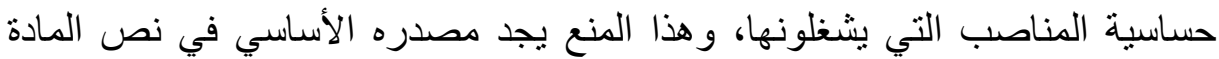

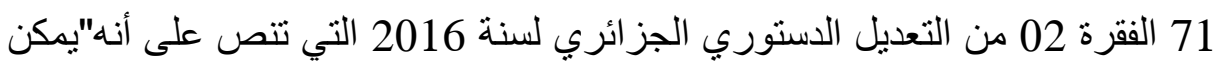

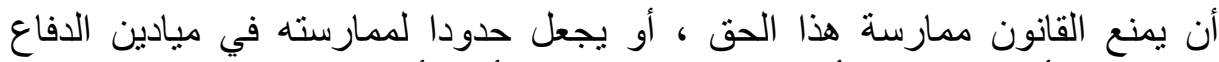

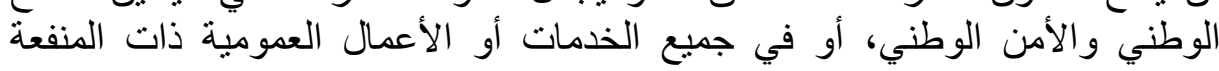

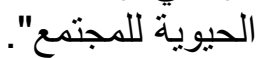

و هو ما نظمه القانون المنظم للإضراب، حيث نصت المادة 43 على ما

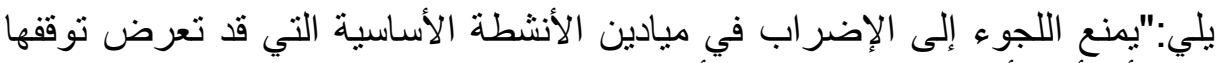

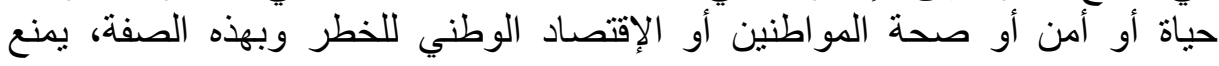




$$
\text { اللجوء إلى الإضر اب على: - إمنى }
$$

- القضاة.

- الموظفين المعينين بمرسوم أو الموظفين الذين بشغلون مناصب في الخارج. - أعوان مصالح الأمن.

- الأعوان الميدانيين العاملين في مصالح الحماية المدنية. - أعوان مصالح استغلال شبكات الإشارة الوطنية في وزارتي الداخلية والثؤون الخارجية. - الأعوان الميدانيين العاملين في الجمارك. - عمال المصالح الخارجية لإدارة السجون".

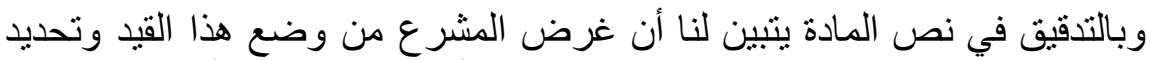

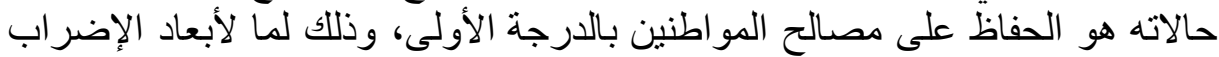

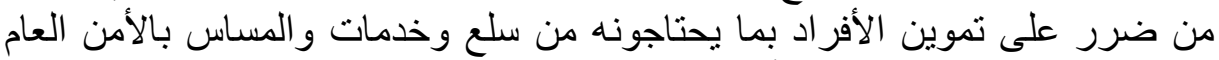
للبلاد وضياع المصالح المالية أو الإقتصـادية للبلاد.

$$
\text { الفرع الثاني : أثـار الاضـــــراب. }
$$

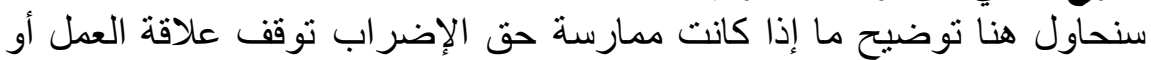

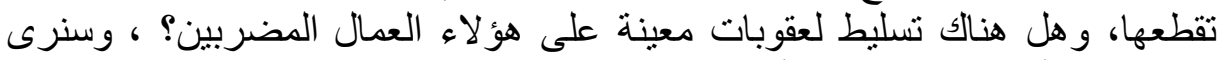

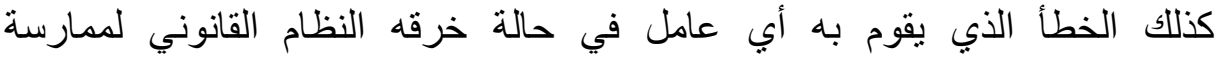

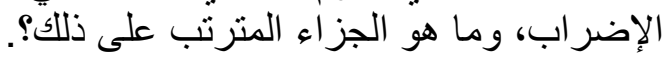

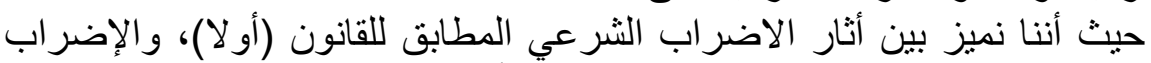

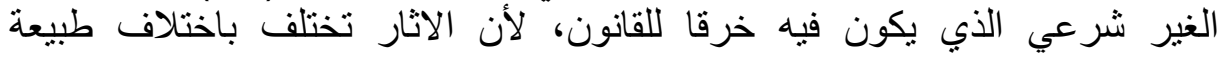

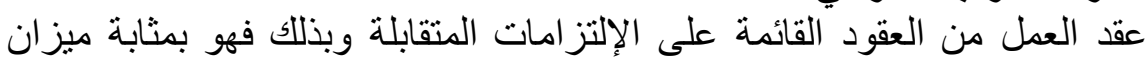

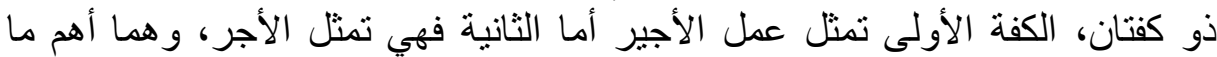

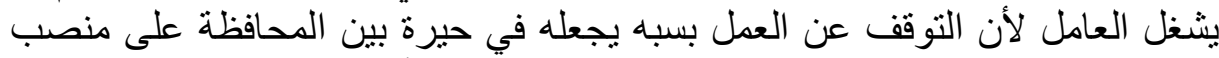

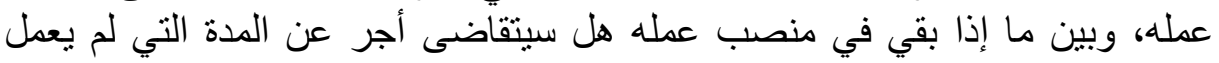

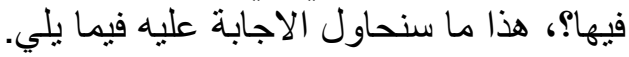

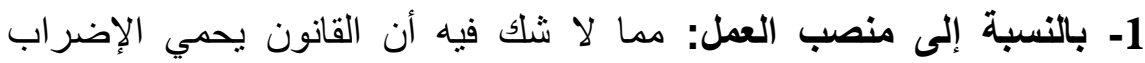

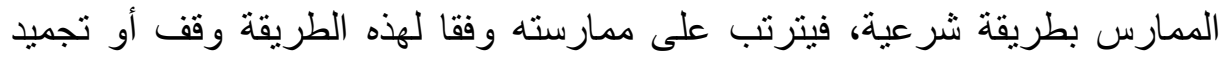

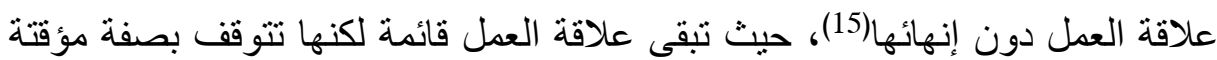

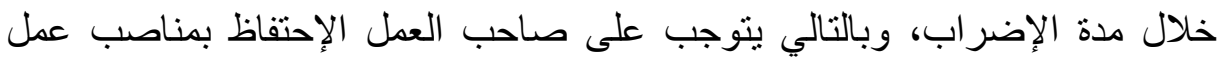

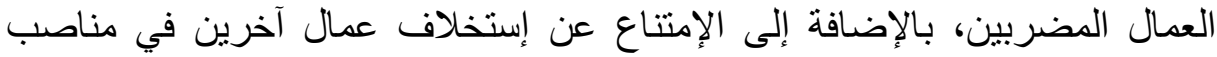
العمال المضربين إلا في حالة التسخير (16)، أو في حالة رفض الإن العض العمال المضربين

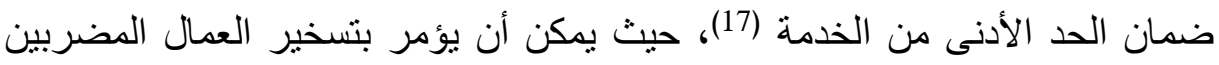

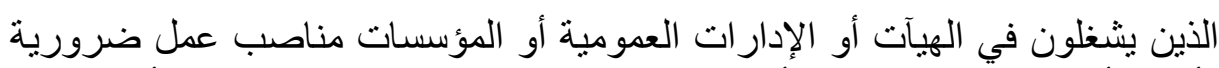

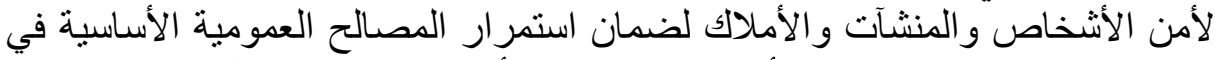

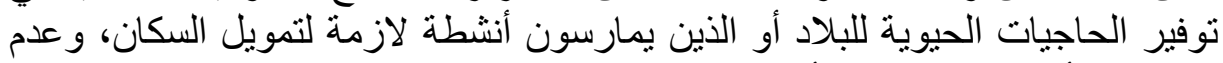

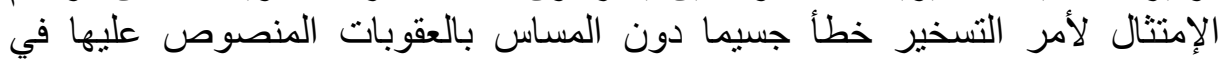


القانون الجز ائي.

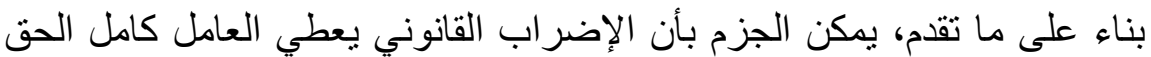

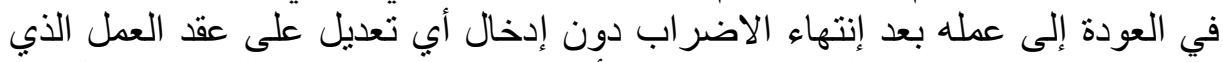

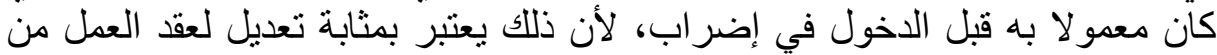

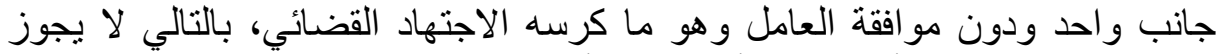

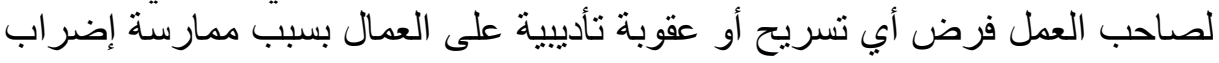
مشروع. - مباح.

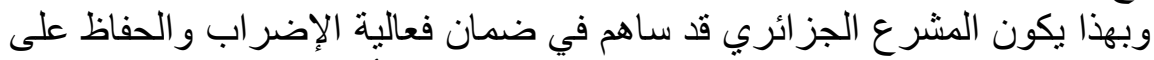

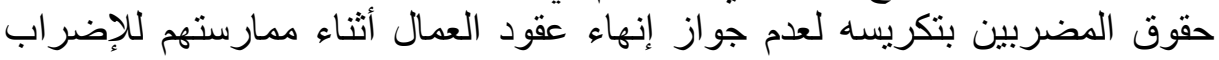

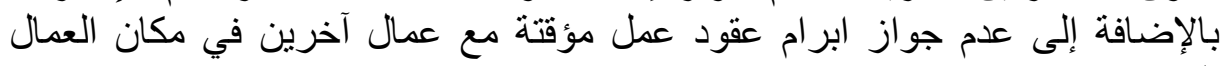
المضربين.

2- بالنسبة إلى الأجر: يعتبر الأجر عنصر جوهري ومهم في عقد العمل، وهو

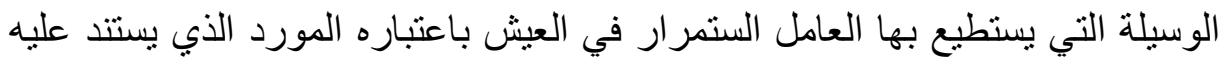

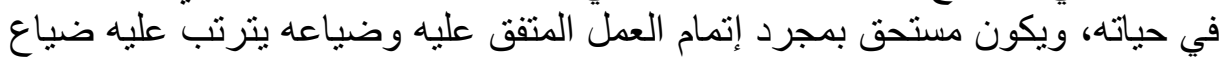
العديد من الحقوق المالية.

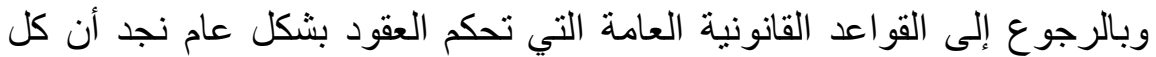

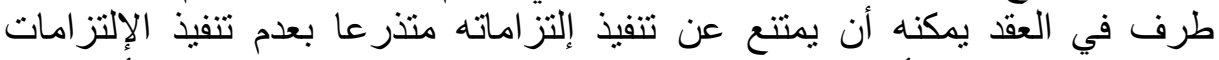

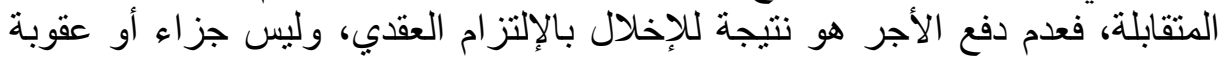
تفرض على الأجير طالما أن عقد العمل معلق كما في هذه الحالة.

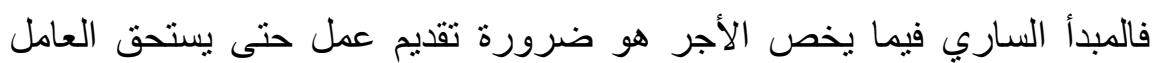

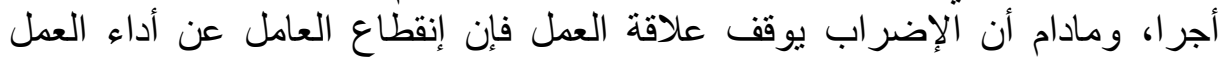

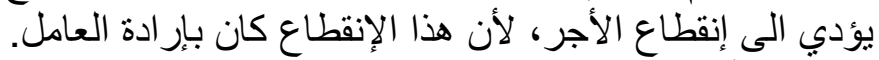

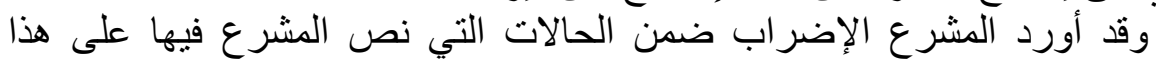

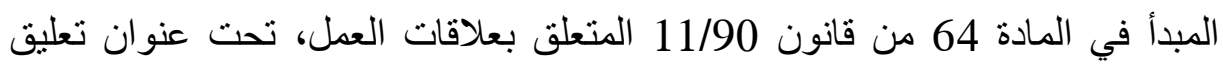
علاقة العمل وهي حالات لا يستحق فيها العامل أجرا لأنه لم يقدم عملا خلال العال هذه الفترة.

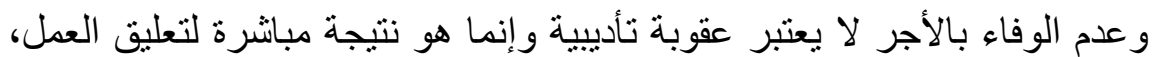

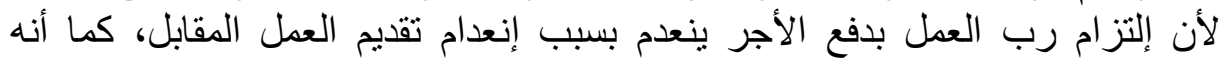

تتوقف كل المنح وملحقات الأجر الأخرى(18). ثانيا: الإضراب الغير شرعي وآثاره.

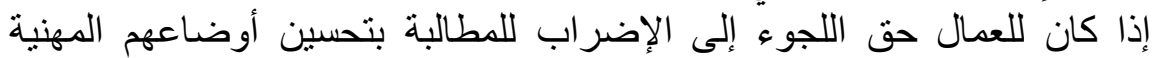

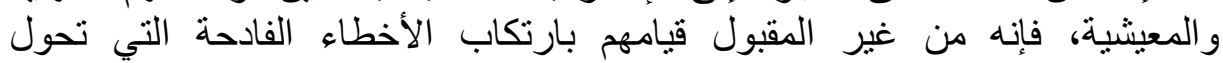

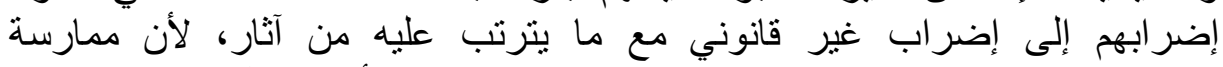

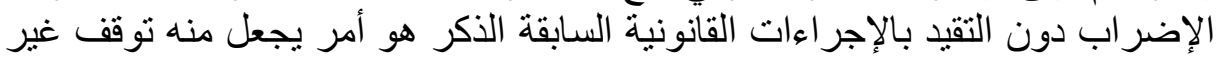

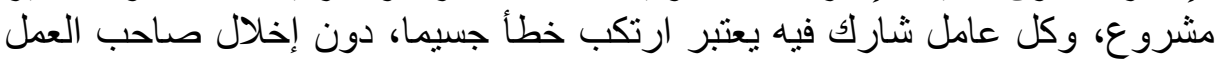
بالإجر اءات التأديبية اللازمة. 1- إعتبار الإضراب الغير قانوني خطأ جسيما: يعتبر المشرع الجزائري كل

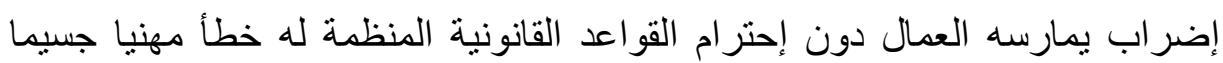

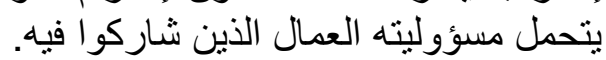

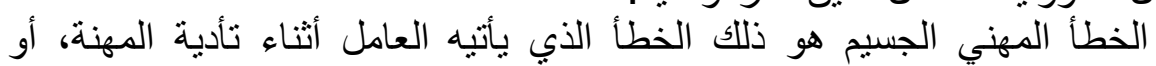

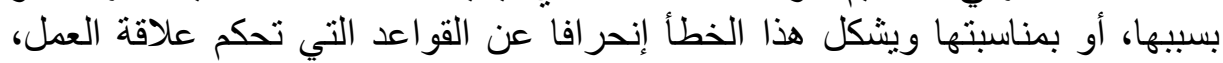


يستحيل معه الإبقاء على العامل بمنصب عمله دون أن يلحق الضرر بالمؤسسة

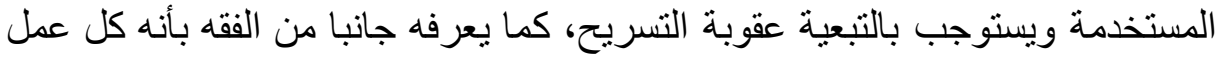
ينتج عنه ضرر بنظام الهيئة المستخدمة(19). ويمكن إضافة خطأين جسيمين متعلقين بالإضر اب واردين في القانون02/90 إذ هو مقيد كذلك بما يسمى بالحد الأدنى من الخدمة بصورة إجبارية، وعدم عرقلة حرية العمل(20)، فيما يخص بضرورة ضمان بـان الحد الأدنى من الخدمة نجد المادة 39 من القانون 02/90 تتص على أنه:"يحدد القدر الأدنى من الخدمة في ميادين النشاط المنصوص عليها في إتفاقية أو عقد جماعي"، و أضافت المادة 40 من ذات القانون ما لـا يلي:" يعد رفض العامل المعني القيام بالقدر الأدنى من الخدمة المفروضة عليه خطأ مهنيا جسيما"، كما أن إضراب العمال مقيد كذلك بعدم عرقلة حرية العمل المنصوص عليها في المادة 34 من نفس القانون، ونصت المادة 36 من نفس القانون على

أنه:"تشكل عرقلة حرية العمل خطأ مهنيا جسيما دون المساس بالعقوبات الجزائية". هذا ويجوز للغير المتضرر من الإضراب المطالبة بالتعويض منى أثبت أن هذا الضرر ناتج عن الإضراب الغير مشروع(21). 2- العقوبة المقررة للإضراب الغير مشروع: مما سبق التطرق إليه، الإضراب الغير قانوني يرتب جزاءات بحق من شارك فيه وأدى إلى خروجه عن مقصديه

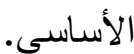

فبالرجوع إلى المادة 33 مكرر من القانون 02/90 نجد أن المشرع إعتبر التوقف

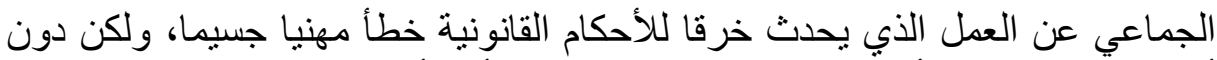
أن يحدد العقوبة التأديبية المنرتبة عن هذا الخطأ، وأجاز لصاحب العمل مباثرة

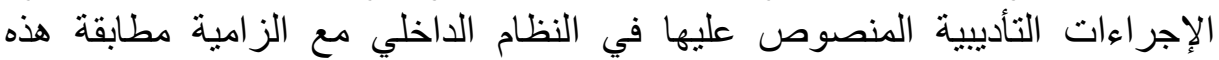

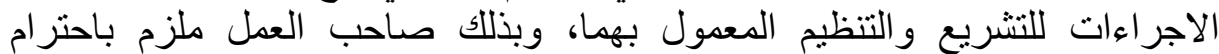
الإجراءات التأديبية المنصوص عليها في النظام الداخلي، وكذا إحترام إجراءات التهات

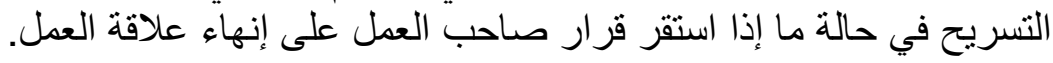

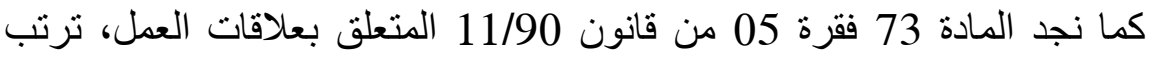
على الإضراب غير الثرعي جزاء تأديبيا يتمثل في التسريح التأديبي من دون فئن مهلة إخطار و لا علاوات لأنه خطأ جسيم(22).

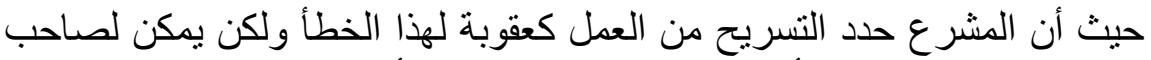

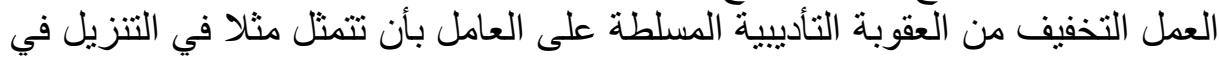
الدرجة أو الخصم من الراتب(23).

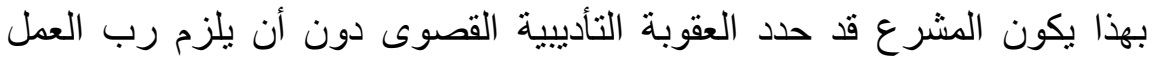

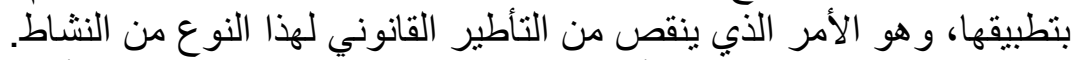

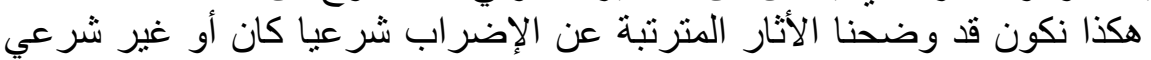

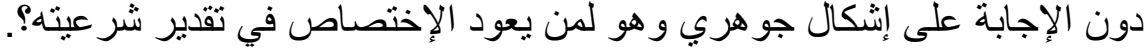

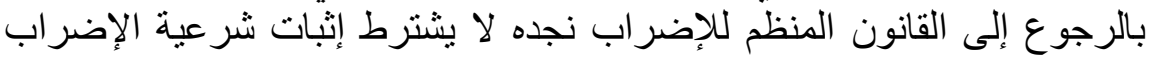

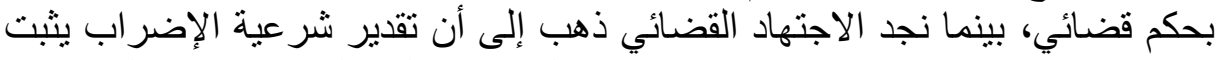
بحكم قضائي حيث يكون على صاحب العمل الحصول قبل تسريح عامل مارس الإن 
إضراب غير مشروع الحصول أولا على حكم أو أمر قضائي يبث في شرعية

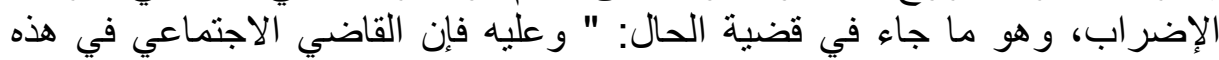

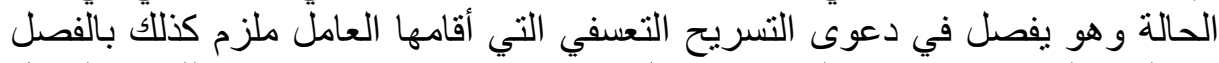

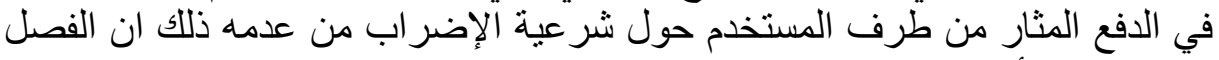

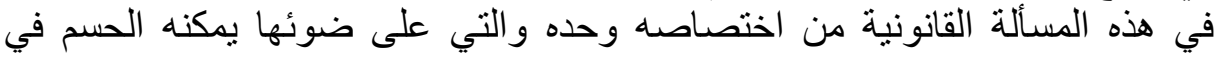

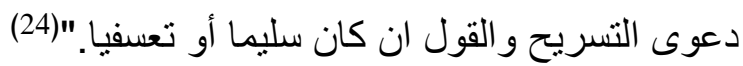

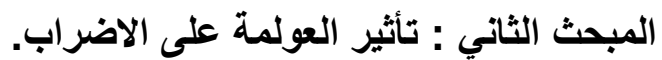

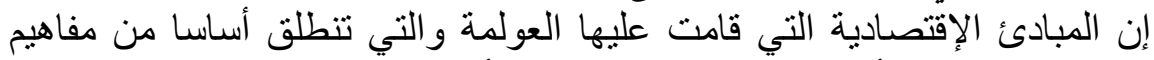

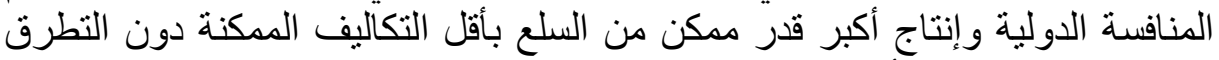

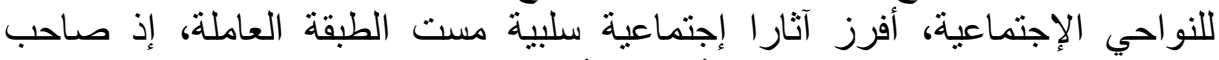

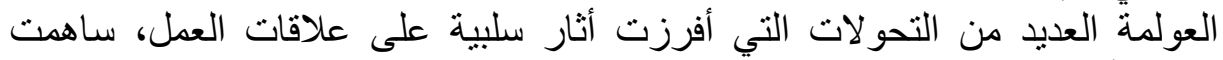

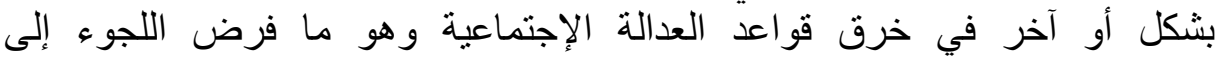

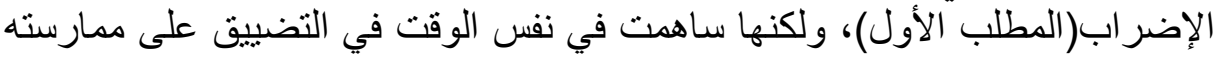

المطلب الأول: الإضراب كنتيجة للآثار السلبية للعولمة على علاقات العمل.

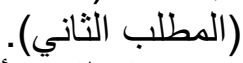

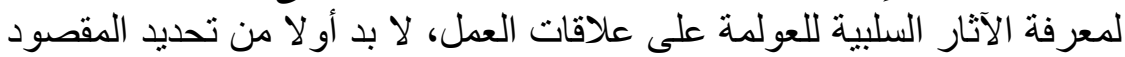

\section{الفرع الأول: تعريف العولمة.}

أطلق مصطلح العولمة لأول مرة في نهاية الستينات من قبل عالم المات السوسيولوجيا

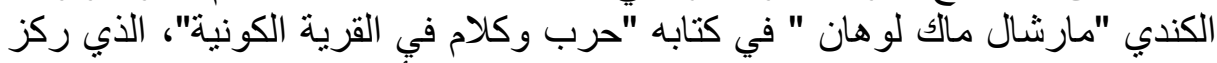

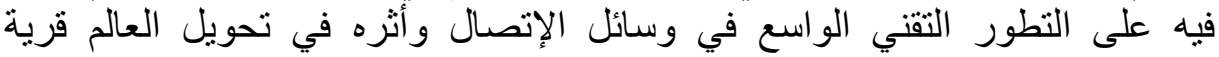
صغيرة) (25).

كلمة عولمة هي ترجمة للمصطلح الفرنسي Mondialisation، والإنجليزي

.Globalisation لغويا، لقد جاء قرار مجمع اللغة العربية بالقاهرة بإجازة إستعمال مصطلح

العولمة بمعنى جعل الثيء عالمبا، أي جعله وكأنه في منظومة و احدة متكاملة(26).

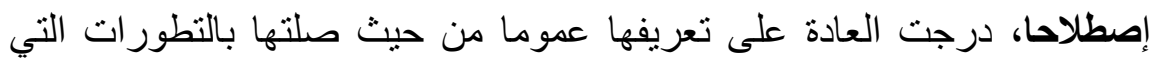

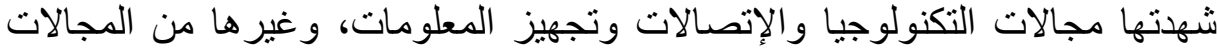

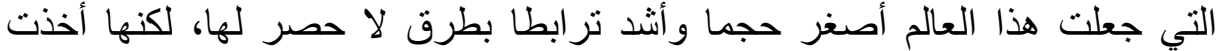

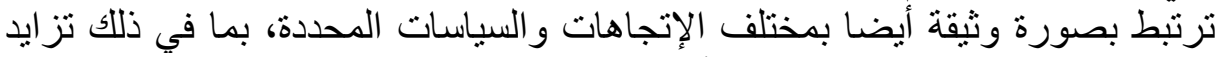

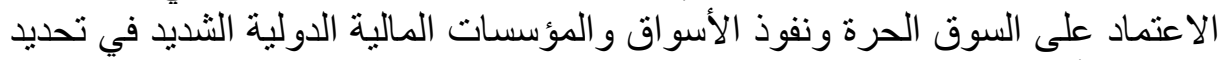

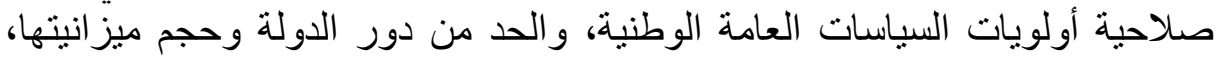

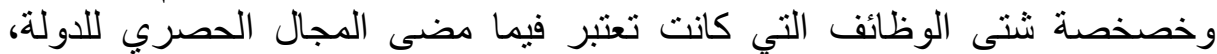

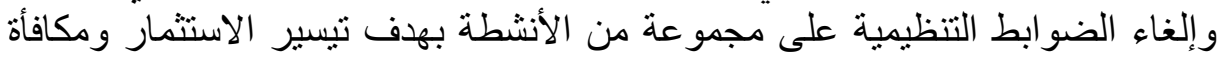

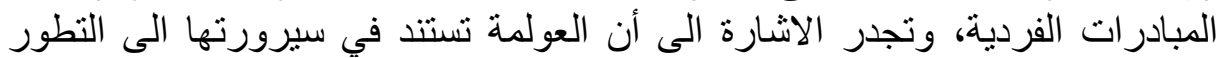
الكبير في تقنية الاتصالات والمعرفة الذي يعد نتيجة ما يطلق عليه بالثورة التقنية

و المعرفية(27).

عرفها صندوق النقد الدولي بأنها:" التعاون الإقتصادي المتبادل بين مجموع دول

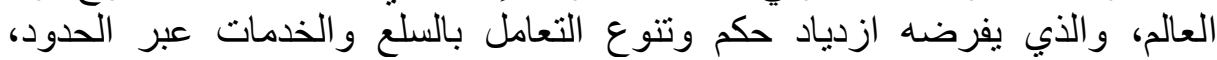

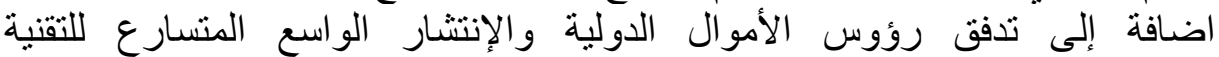
و التكنولوجيا في أرجاء العالم كله"، هذا التعريف الذي الأيركز على الجئ الجانب الاقتصادي 
للعولمة فقط.

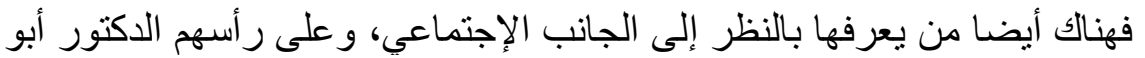

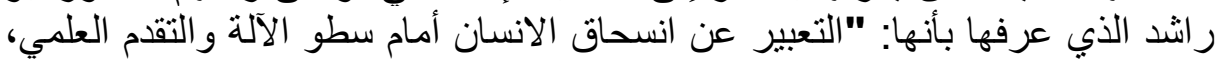

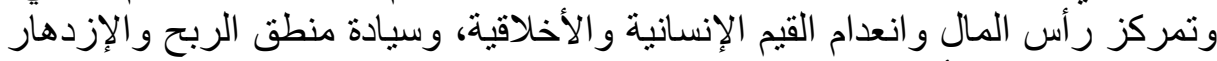
الفردي والبقاء للأقوى، من خلال تجارة السوق المعلوماتية والاستيلاب التقافي الإني

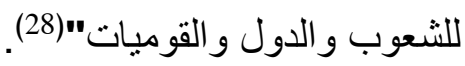

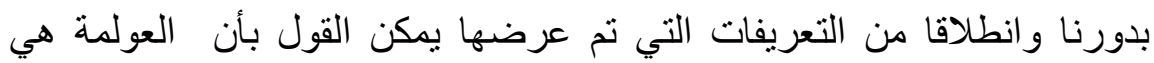

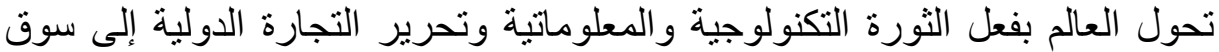

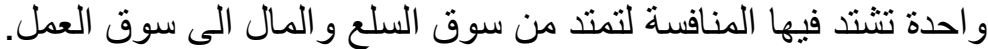

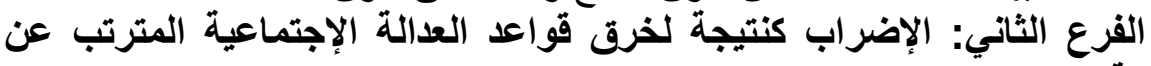

إن إقرار قانون العمل الجز ائري لممارسة حق الإضر اب ما هو إلا أثرا مباثشرا العولمة.

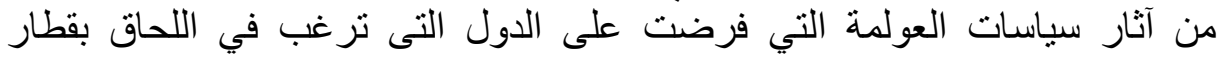

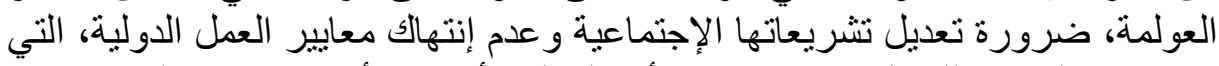

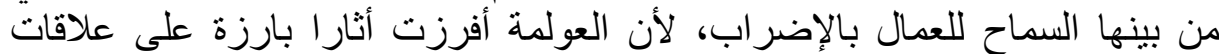

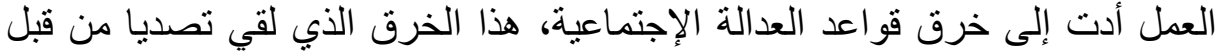

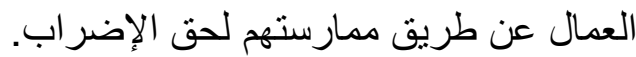

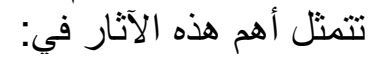

أولا: اللجوء إلى العمل المؤقت : ذلأن من أجل إضفاء مرونة أكثر على التعاقد،

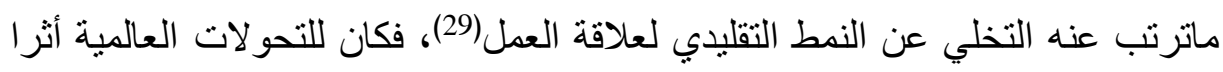

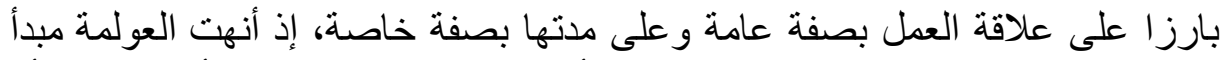

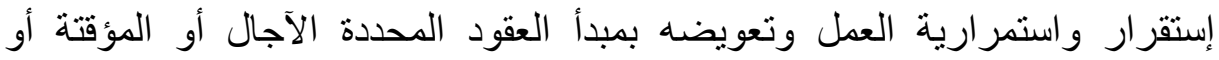

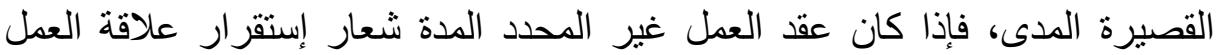

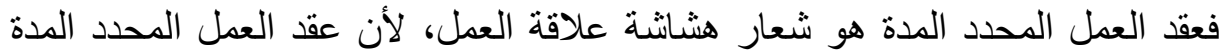

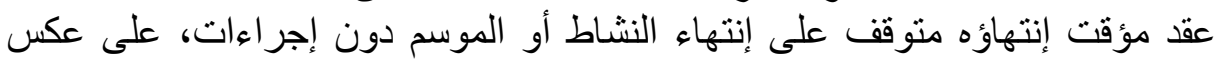

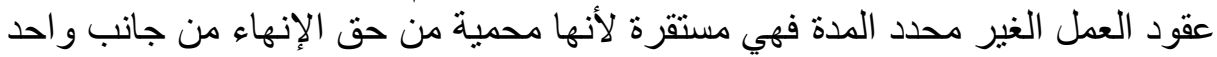

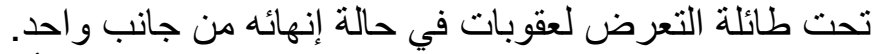

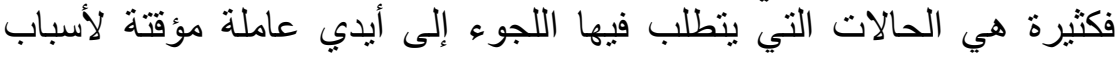

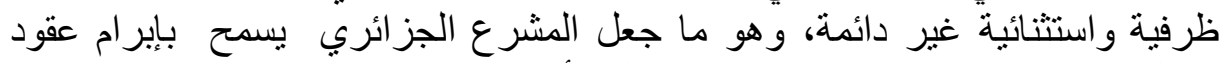

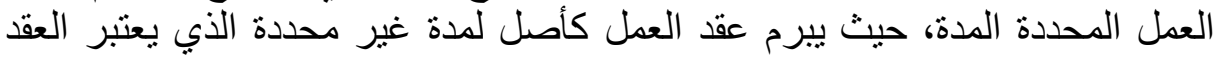
المثالي، فحدد المشرع حالات اللجوء إلى إبرام عقد عمل محدد المدة وفقا للمادة 12

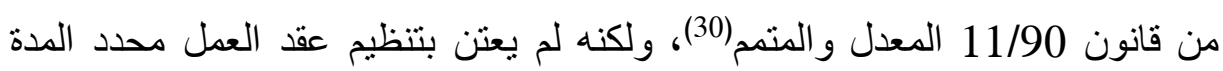

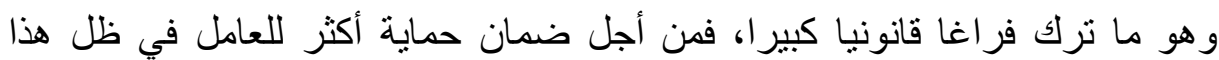

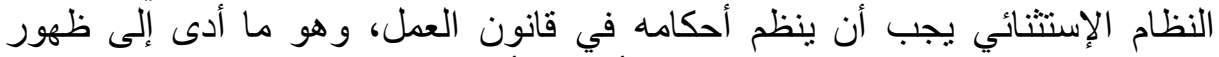

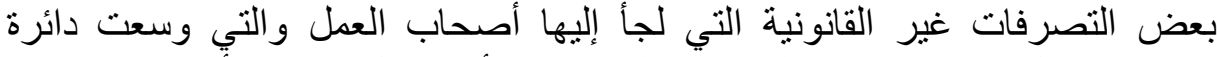

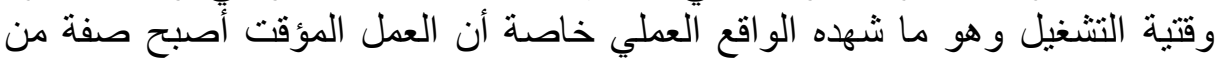

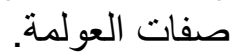

ثانيا: تسريح العمال: مع إنتشار العولمة وبروز تأتثاتير اتها على كافة نواحي الحياة

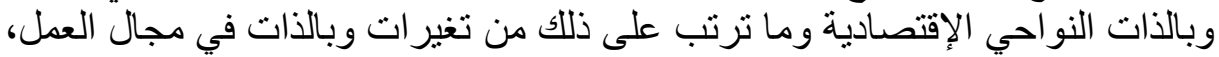

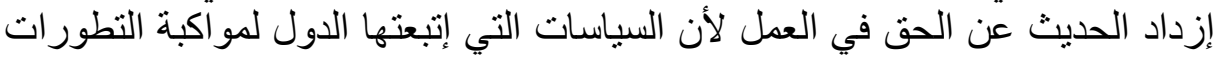

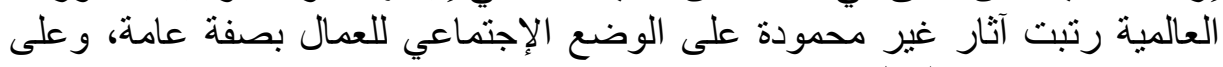
إستمر ارية علاقات العمل بصفة خاصة 
فنظام العولمة الراهنة تضمن إلغاء الثركات الكبرى الإحتكارية الآلاف من إناف

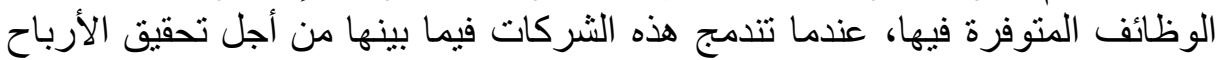

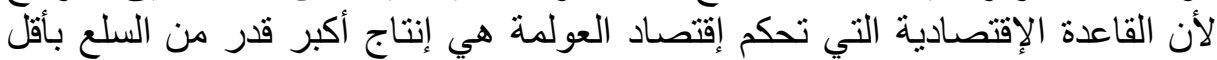

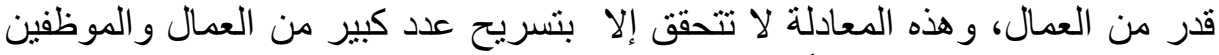

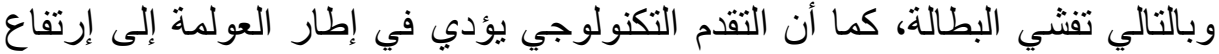

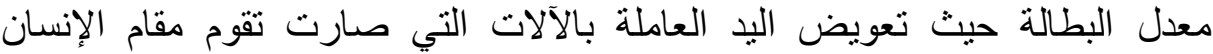

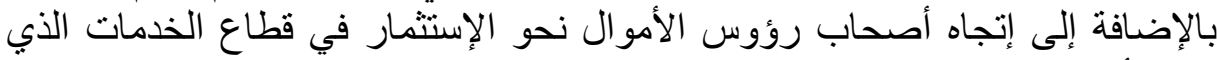
يعتمد أكثر على تكنولوجيات الإتصال و عدد قليل من اليد العاملة.

كما أنه من أبرز النتائج المترتبة على العولمة هي الخوصصة أو خصخصة

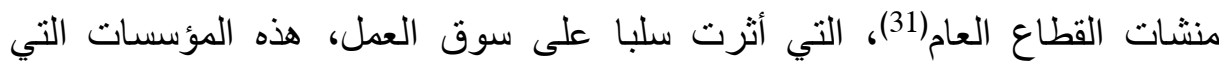
عملت على الحفاظ على العمال الذين يتميزون بخصائص تأهلهم في البقاء في لتئي

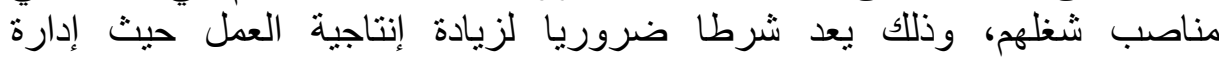
المشروعات بالبحث عن الكتلة العمالية اللازمة لإستمرار العمل، ولهذا لئاد عملت غالبية

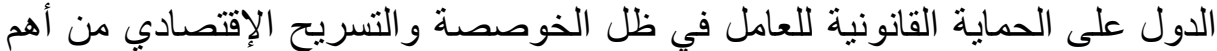

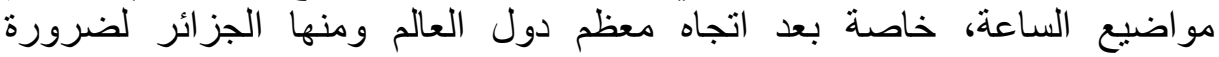

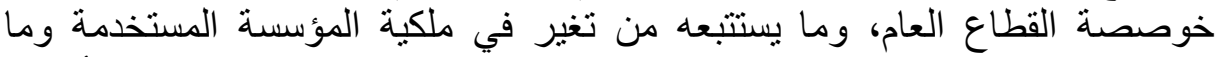

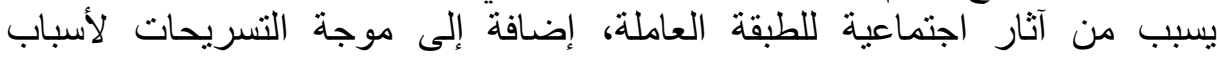

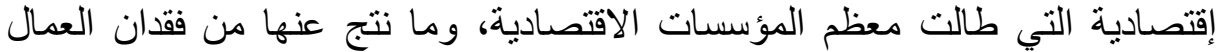

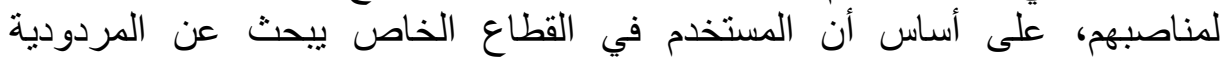
الإقتصادية ولو كانت على حساب حقوق العمال ومكاسبهر. و على الرغم من إصدار المرسوم التشريعي 09/94 المتعلق بالحفاظ على على الثغل وحماية الأجر اء الذين قد يفقدون عملهم بصفة لا إرادية والمؤرخ في 26 مابي 1994،

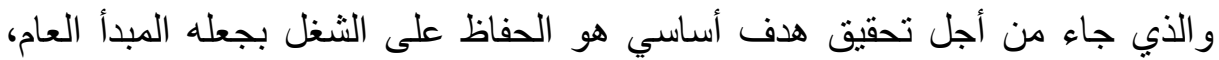

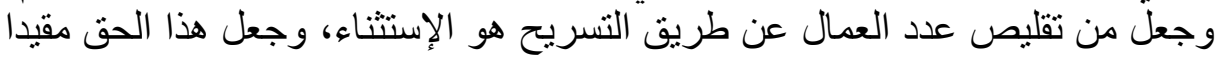

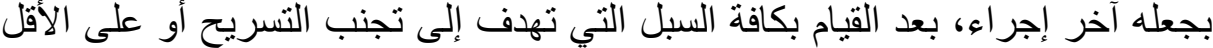

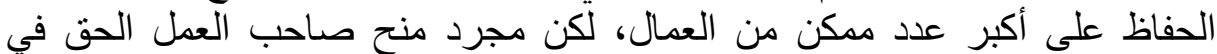

الإنهاء وتسريح العمال، فتح لله المجال واسعا في في إستعمال سلطته في التسريح.

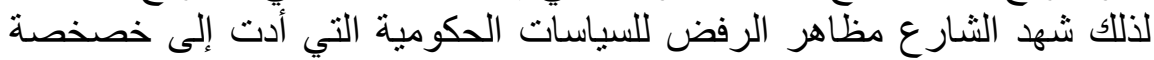

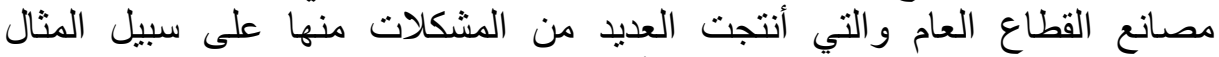

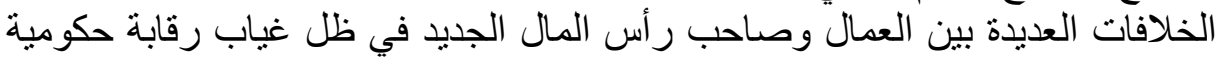

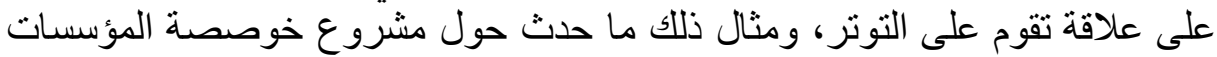

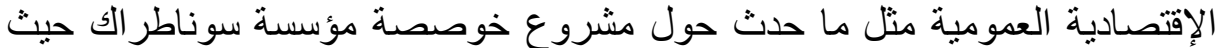

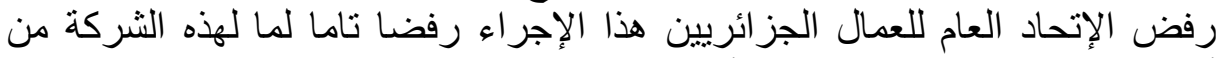

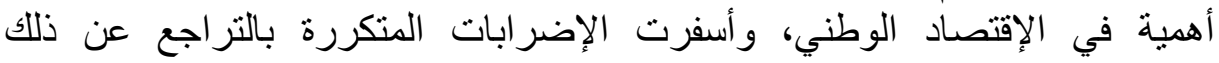

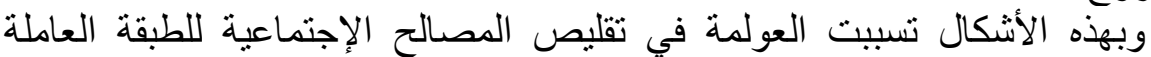

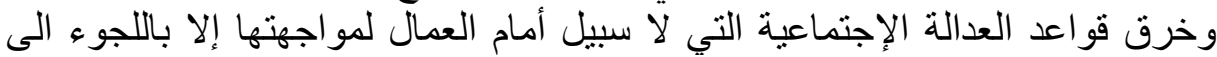

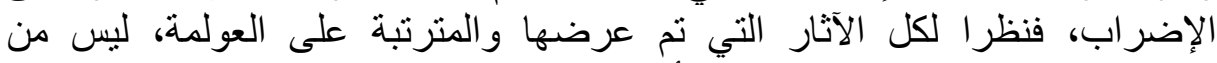

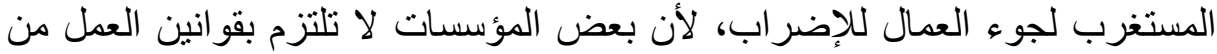

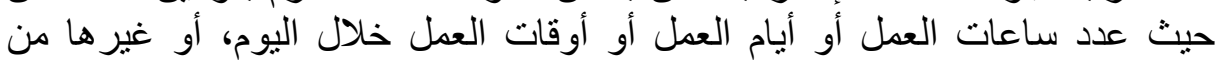
العوامل التي ترهق العامل وتلجئه إلى الإضراب عن العمل، حيث كثفت العديد من 
التقارير التي أصدرتها مفتنيات العمل عن ممارسات تتنافى مع قوانين العمل التهل

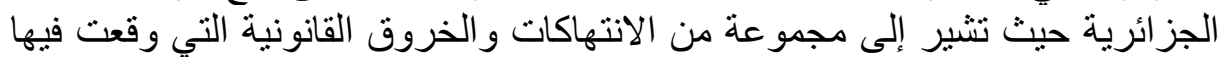

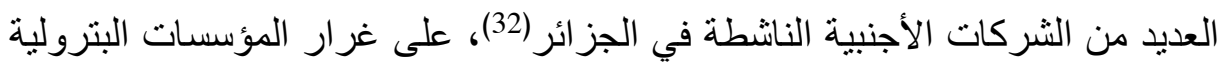

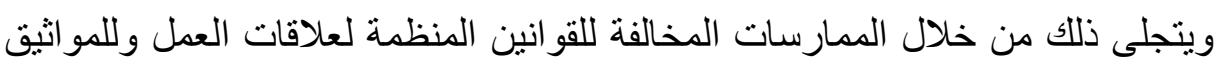

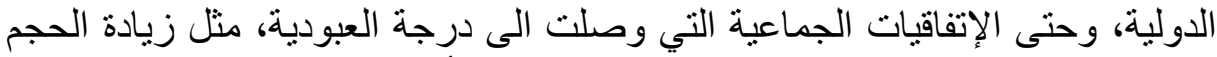

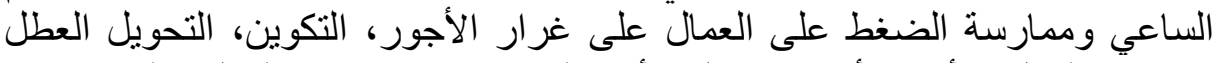

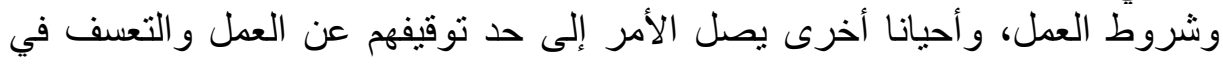

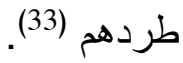

ومن هنا يعتبر الإضراب رد فعلي للعمال نتيجة الأثار السلبية التي أفرزتها

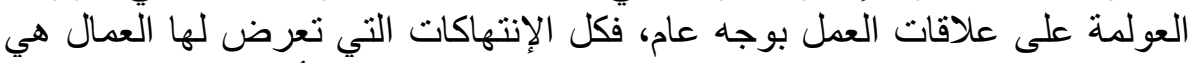

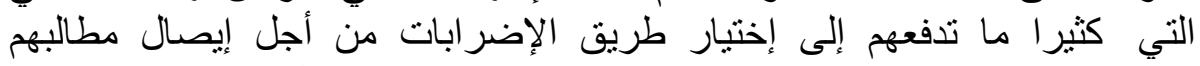

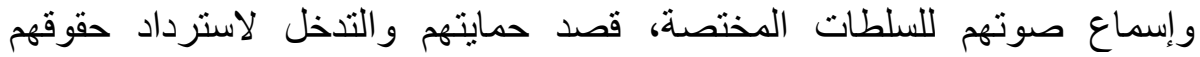

المطلب الثاني: التضييق على حق اللجوء إلى الإضراب في ظل العولمة.

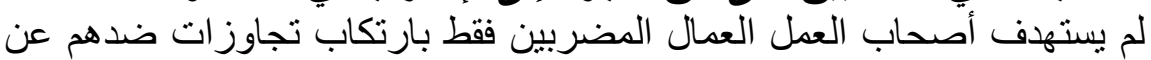

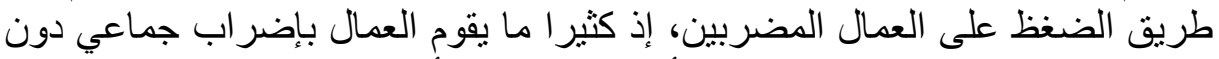

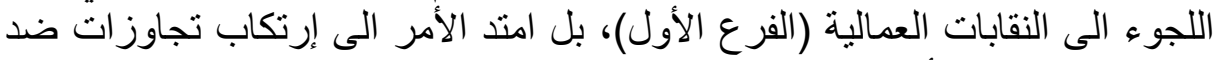

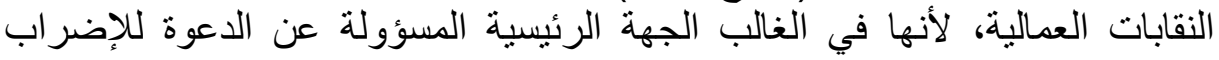

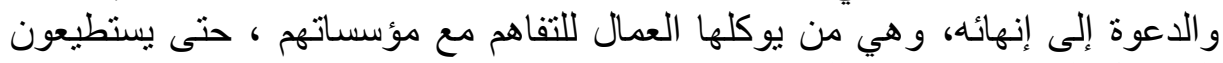

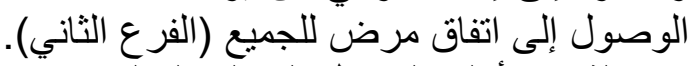
الفرع الأول: الضغط على العمال المضربين.

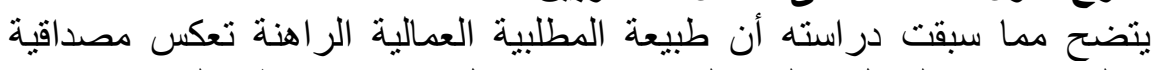

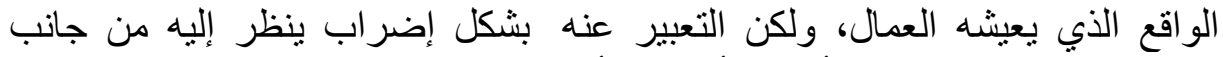

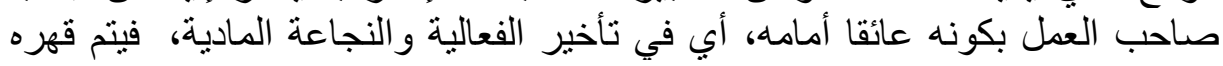

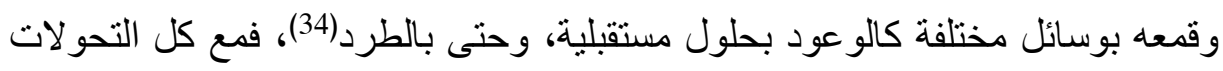

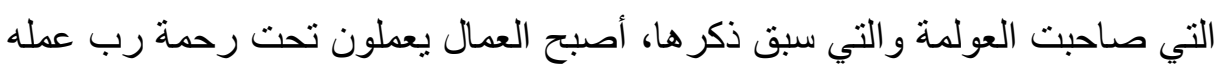

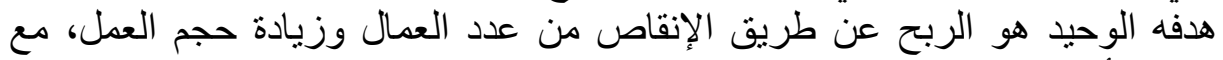

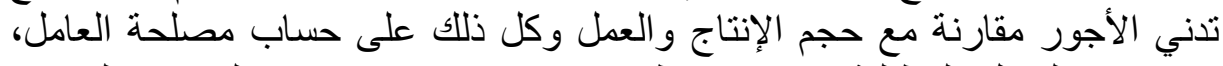

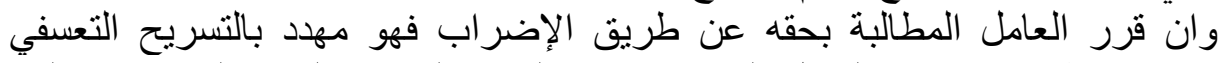

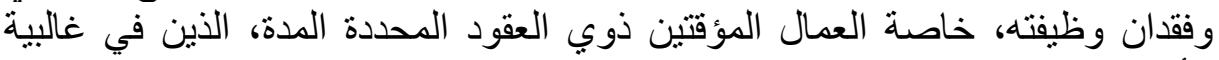

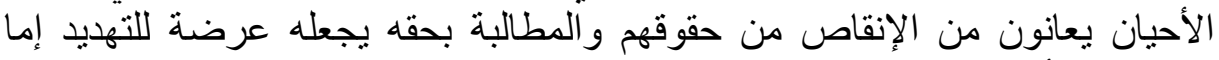

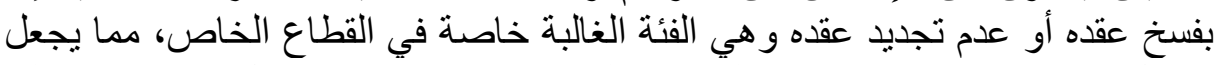

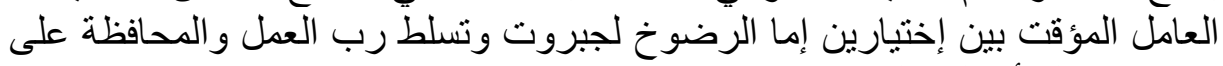

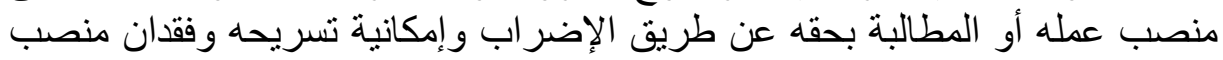

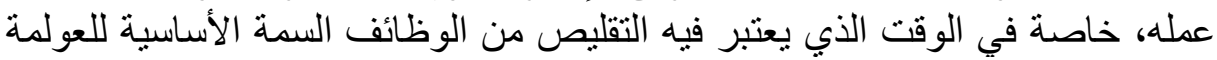

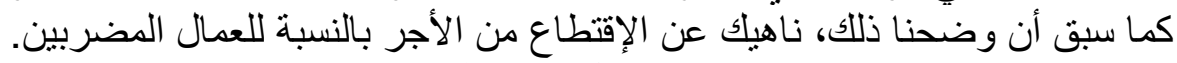

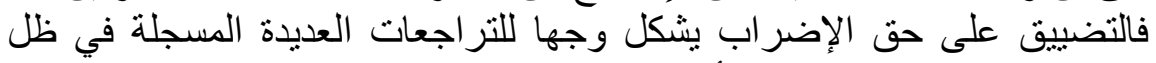

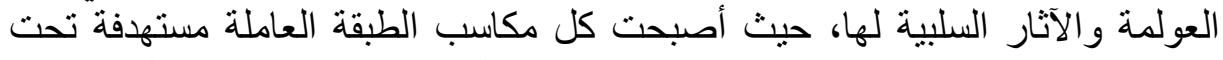

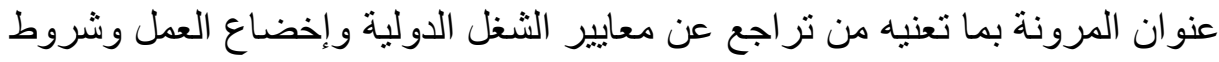

$$
\text { العمل لقانون السوق. }
$$

و هو ما أكده بيان بشأن العولمة وأثرها على التمتع بالحقوق الإقتصادية

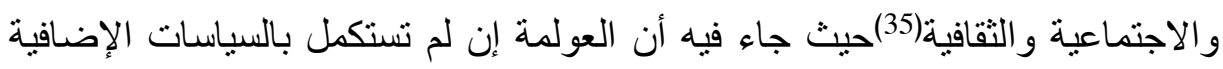


المناسبة، حيث أنها تنطوي على خطر الانتقاص من المكانة الممنوحة لحقوق الإنسان

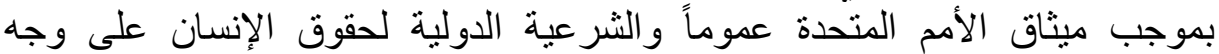

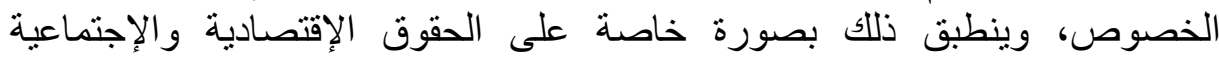

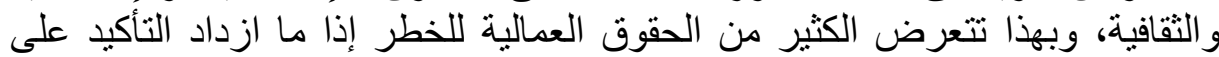

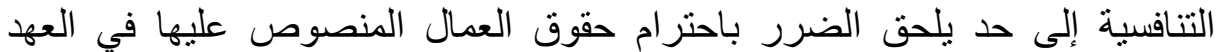

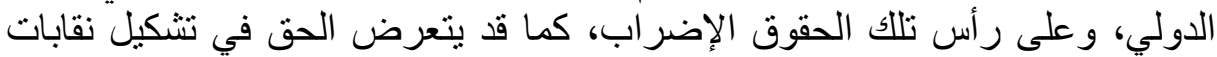

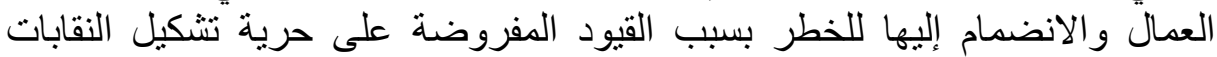

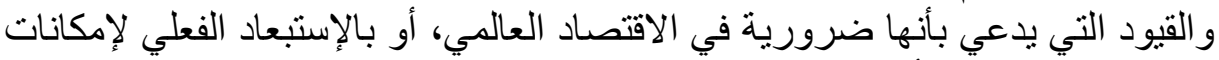

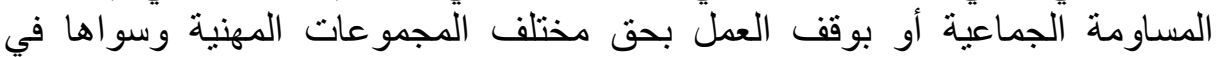

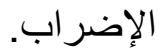

ويقصد بالسياسات الإضافية التي تكلم عنها البيان إصدار مختلف القوانين التي توفر قدر من الحماية للحقوق العمالية بطريقة تتلاءم والظروف التان الراهنة التانة وفي ظل

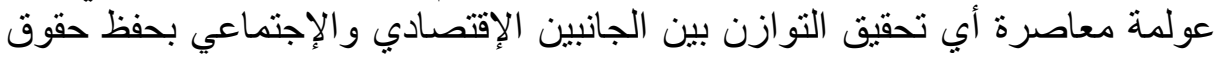

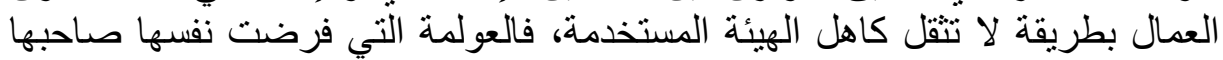

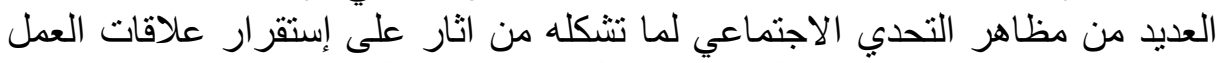

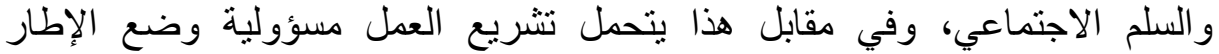

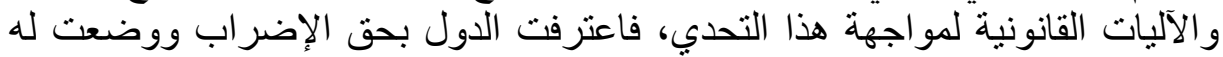

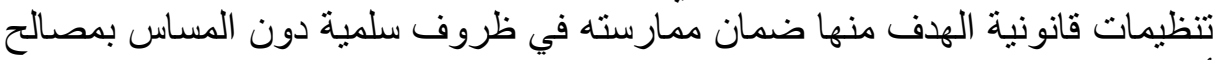

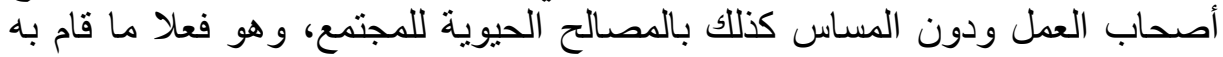

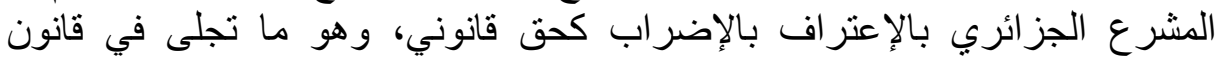

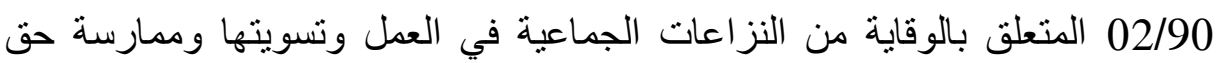

\section{الفرع الثاني: الضغط على النقابات العمالية.}

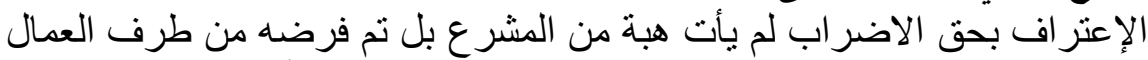

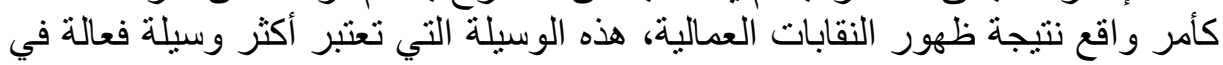

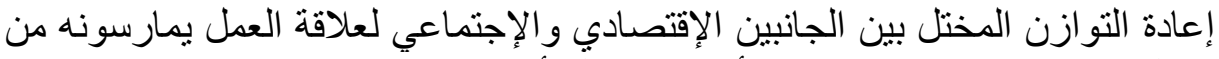

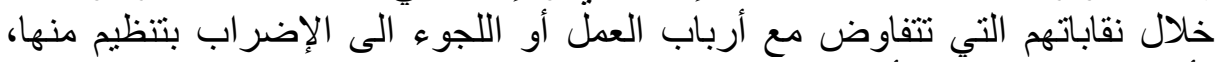

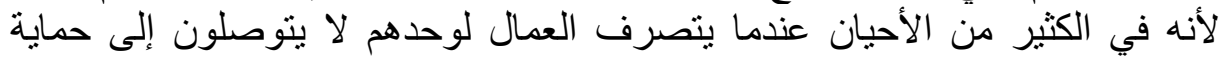

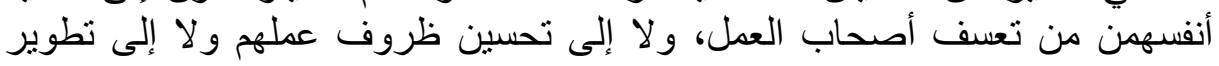
القو انين لصالحهم(36).

لقد أقر الدستور الجزائري الحق النقابي وهو ماجاءت به المادة 70 من التعديل الدستوري لسنة 2016 التي نصت على أنه:"الحق النقابي معترف به لريه لجميع المواطنين"، وطبقا للمادة 40 من قانون 14/90 المؤرخ في2 جوان 1990 المتعلق بكيفية ممارسة الحق النقابي المعدل والمتمم بالأمر 12/96 المؤرخ في نجد المشرع الجزائري اعترف بممارسة الحق النقابي في كل المؤسسات عمومية الماتية

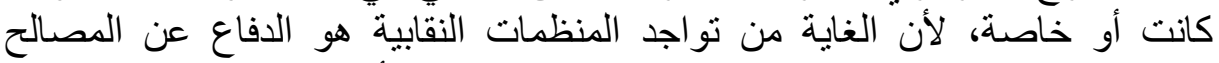

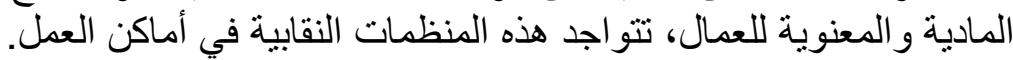

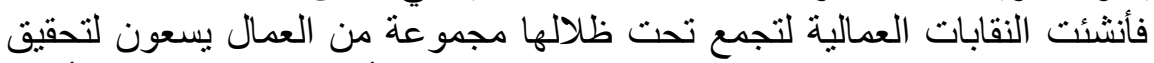

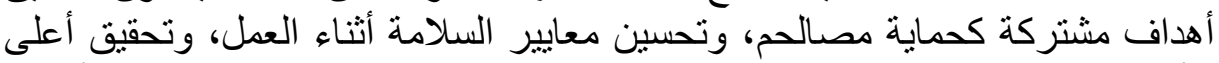

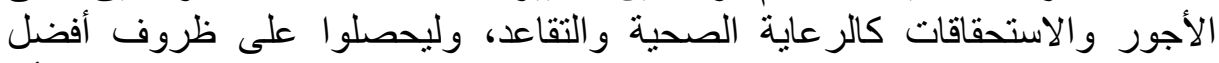

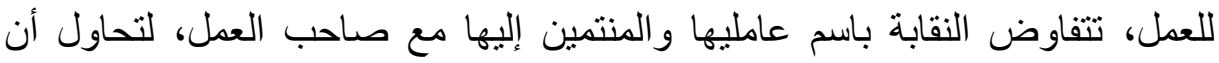


تعمل على تحقيق ما يرجوه المشتركون فيها.

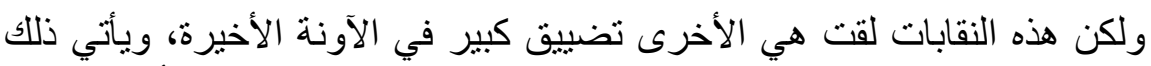

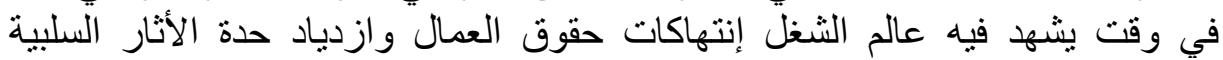

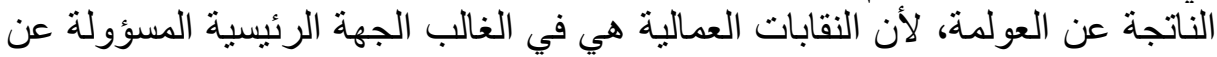

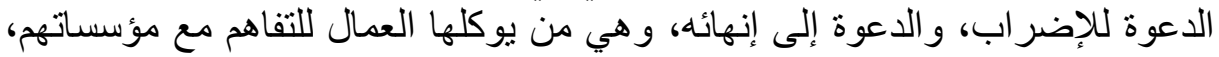

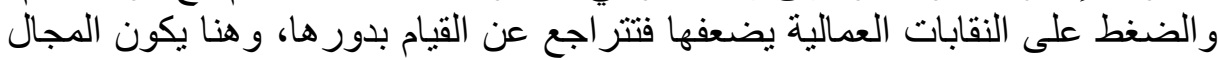

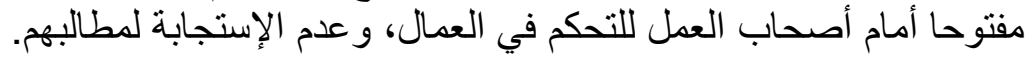

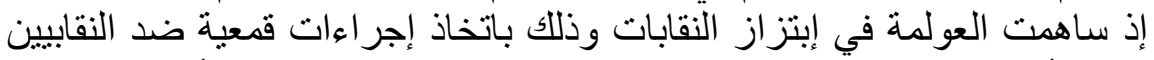

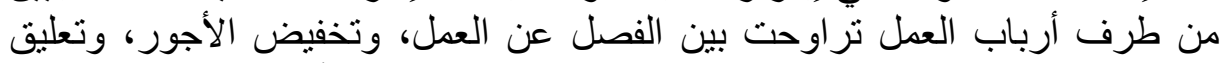

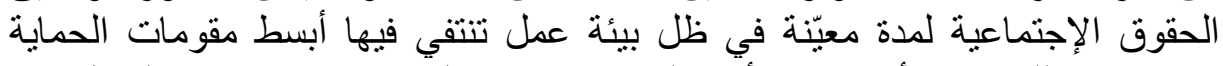

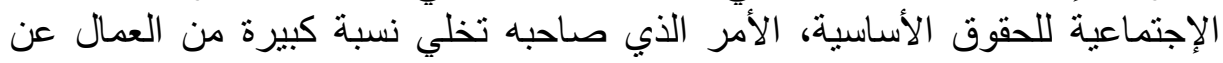

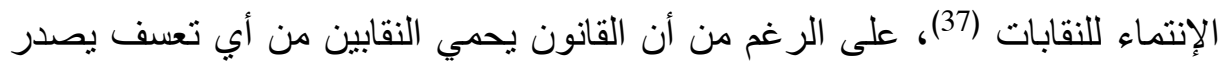

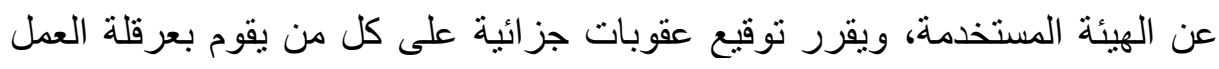

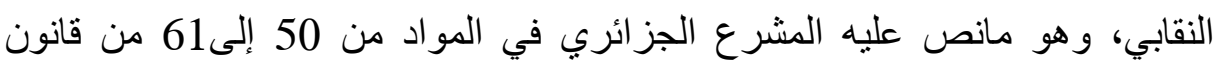

\section{II}

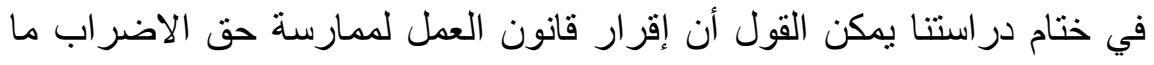

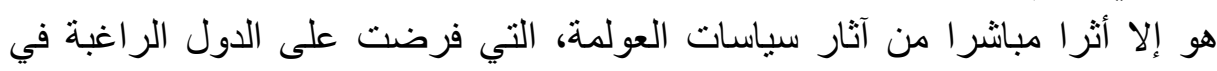

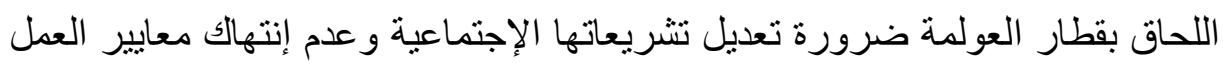

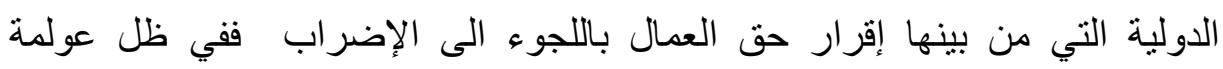

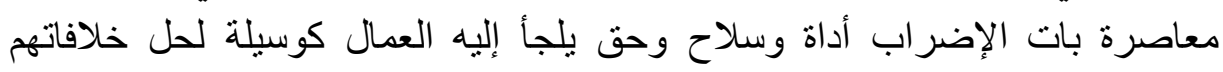

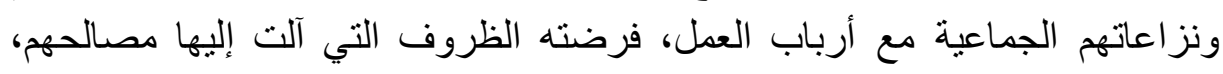

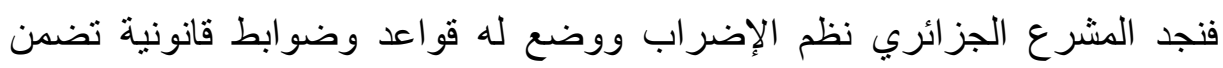

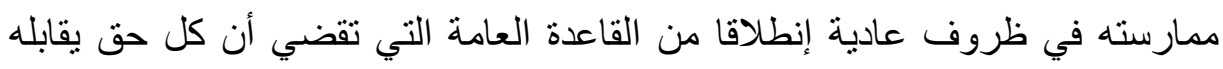

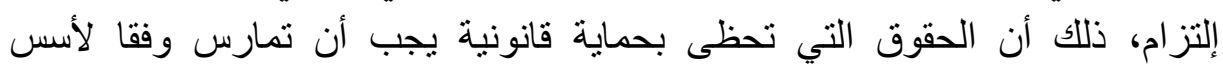

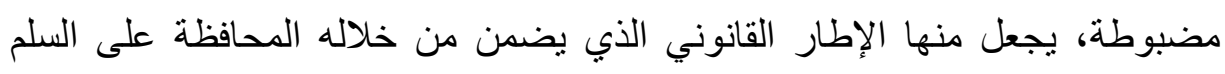

فكان لسياسيات العولمة أثار سلبية كثيرة مست الطبقة العاملة أهمها فقد الأمان الإجتماعي.

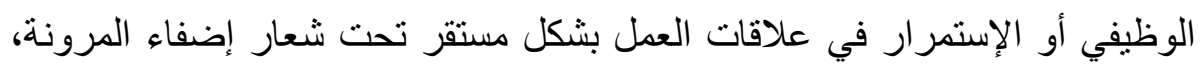

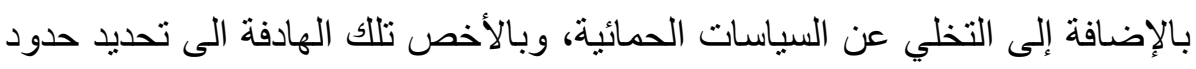

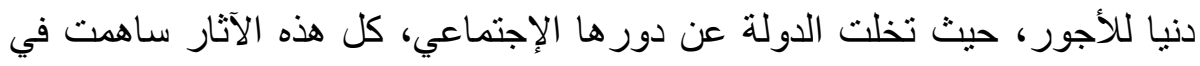

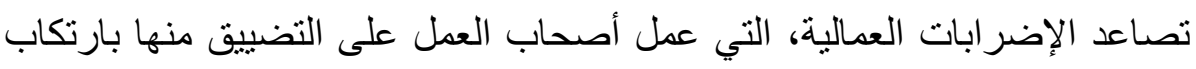
تجاوزات كبيرة.

فنجد القانون ينظم تسوية النزاعات العمالية بدأ من المفاوضة إلى الوساطة في

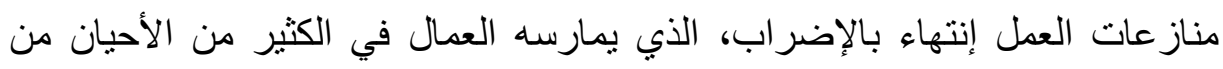

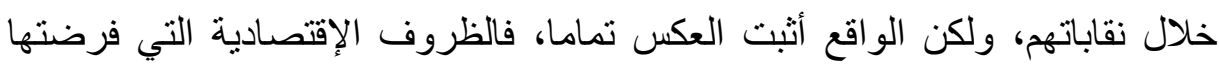

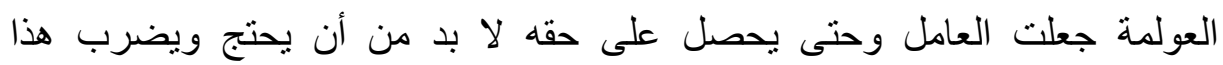


الإضر اب هو الذي يوصله إلى التفاوض والاتفاق مع مستخدمه، وليس العكس كما هو

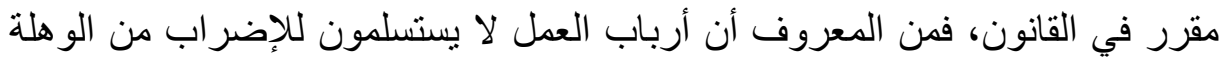
الأولى، فكلما تحاول النقابات العمالية الضغط فلون إنى أرباب البعل العمل من جهة باستخدام

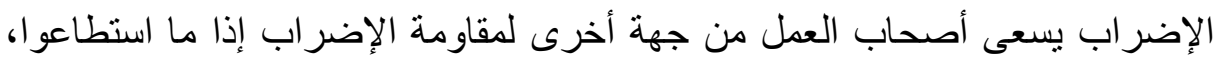
الأمر الذي وصل إلى حدوث تجاوزات كثيرة للقانون وصلت إلى حد التسريح التعسفي

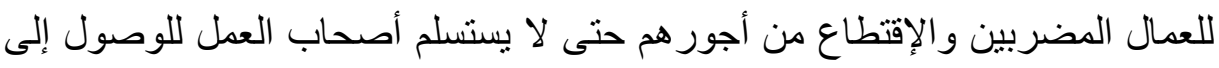

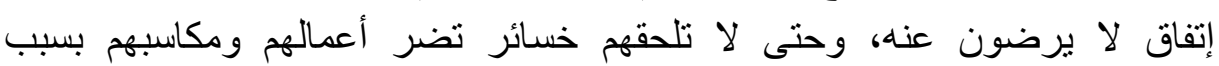

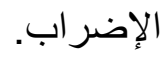

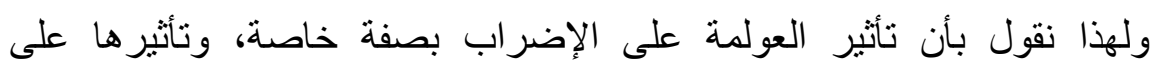

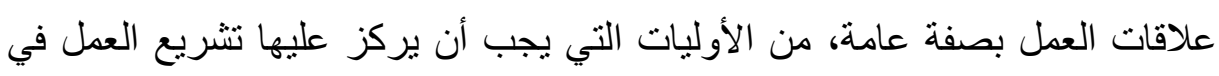

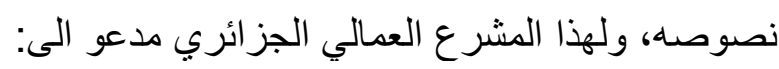
- - تعديل قانون العمل بوجه عام، وقانون 02/90 المتعلق بالوقاية من النزاتئل

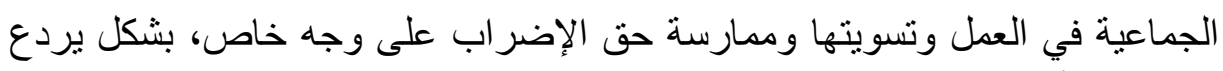

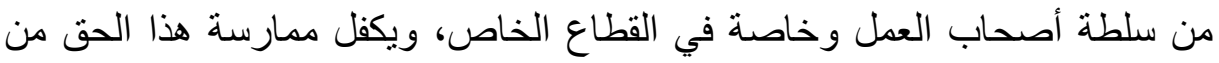

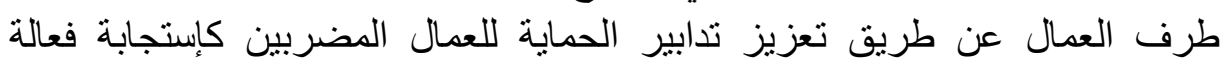

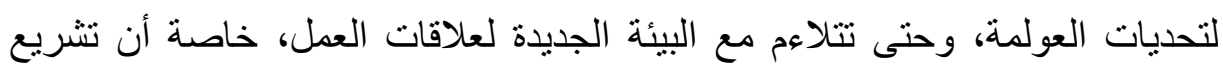

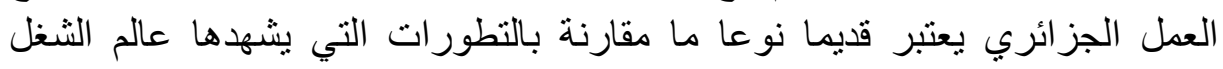
وتأثثير ات العولمة عليه.

- فتح باب الحوار الإجتماعي كركيزة أساسية للوصول إلى توافت الآراء، باعتباره

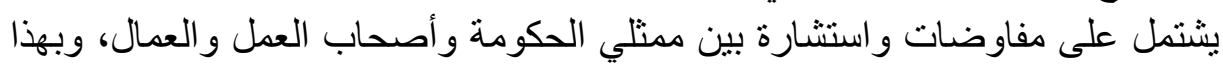

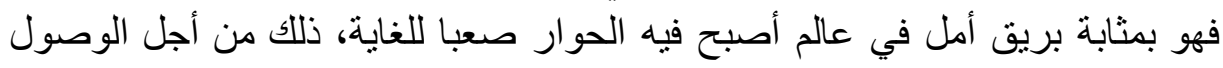
إلى حلول و إرساء سيادة القانون.

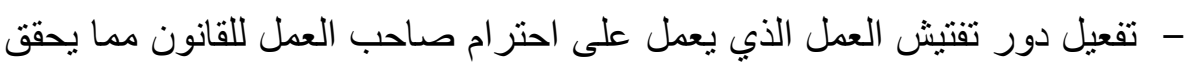

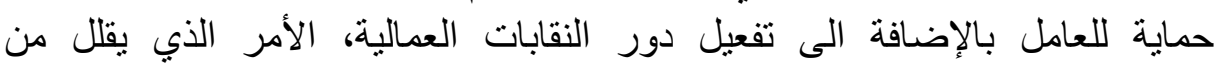
الإضر ابات، وهو ما يحقق مصلحة للطرفين.

المراجح 1. الإضر اب في مصر، تقرير المنظمة المصرية حول الإضرابات والإعتصامات،

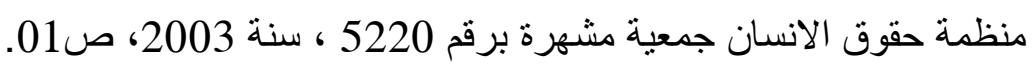

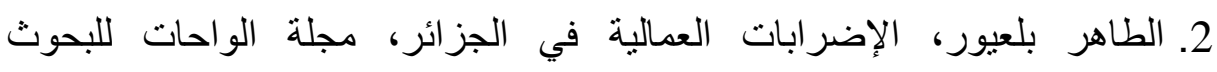

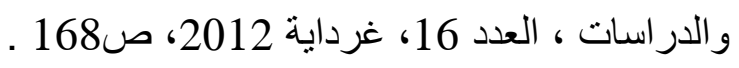

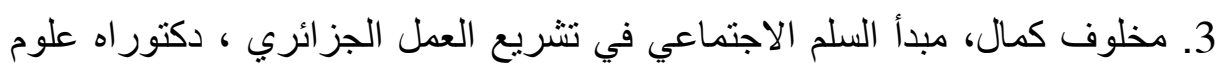

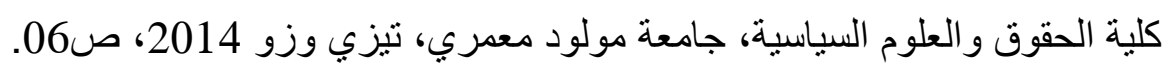

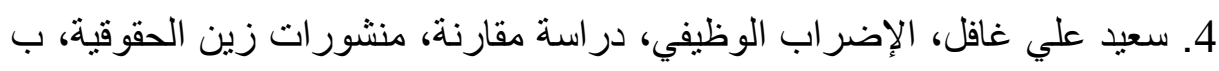

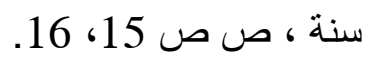


5. اشكالية الحق في الإضراب ، موقع الأنترنت: www.m.ahewar.org

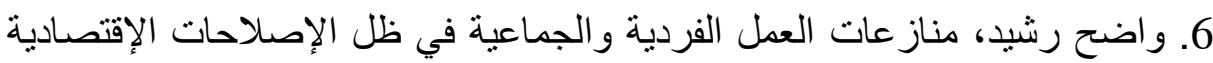

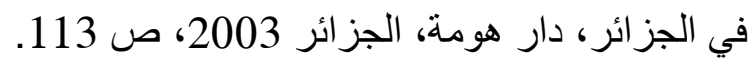

7. أحمية سليمان، الوجيز في قانون علاقات العمل في التشريع الجزائري، ديوان

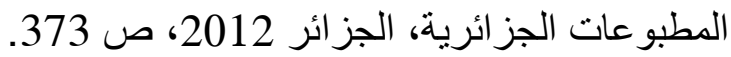

8. نصت المادة 8 من العهد الدولي الخاص بالحقوق الاقتصادية والاجتماعية والثقافية

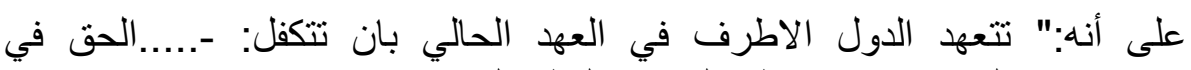

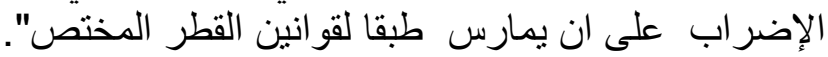

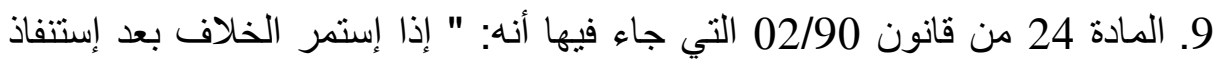

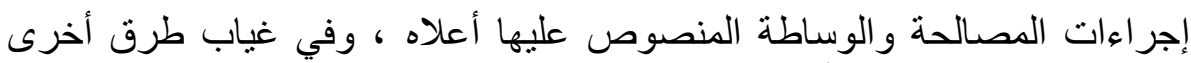

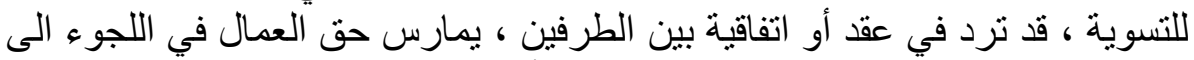

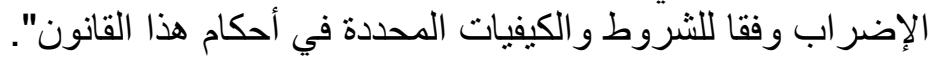

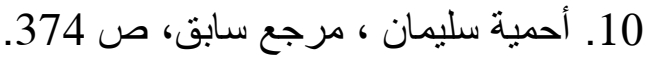

11. بشير هدفي، الوجيز في شرح قانون العمل، جسور للنشر والتوزيع، الطبعة

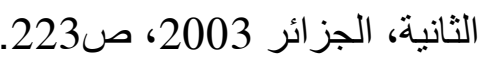

12. Amoura Amar, Droit du travaille et Droit sociale guide pratique, édition el maarifa, Alger 2002, p 2001.

13. مصطفى أحمد أبو عمرو، التنظيم القانوني لحق الإضراب في القانون المصري

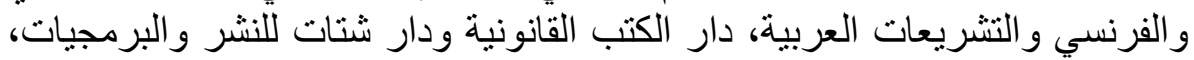

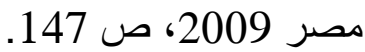

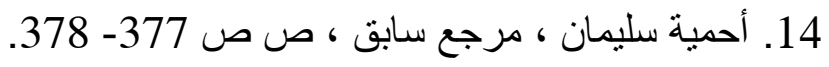

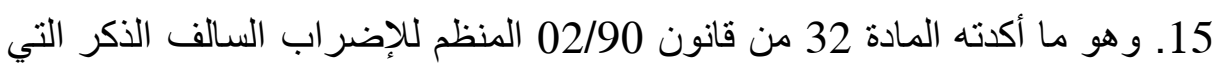
تتص على أنه: "يحمي القانون حق الإضراب الذي يمارس مع احترام أحكام هذا

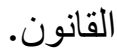

و لا يقطع الإضراب الذي شرع فيه حسب هذه الشروط علاقة العمل."

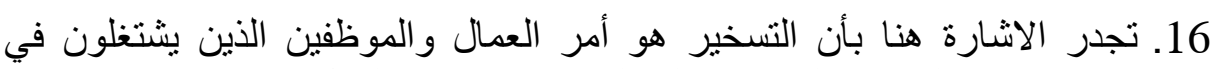
قطاع حيوي في البلاد بالالتحاق بعملهم لضمان الضئ سيرورة العمل في ذلك القطاع.

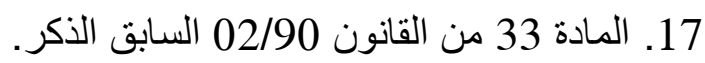

18. أمال بطاهر، النظام القانوني لحماية الأجور في القانون الجزائري، دار الجامعة

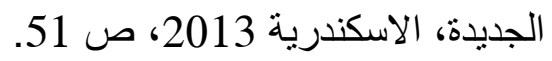

19. سعيد طربيت، سلطة المستخدم في تسريح العمال تأديبيا، ديوان المطبوعات

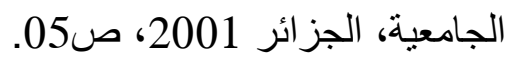

20. Mohamed Nasser Eddine Koriche, tome 01, Droit du travail , office des publications universitaires, Alger 2009,p193.

$$
\text { 21. مخلوف كمال ، مرجع سابق ، ص } 307 .
$$

22. تتص المادة 73 من قانون 11/90 على أنه:"...تعتبر على الخصوص أخطاء 
جسيمة يحتمل أن ينجر عنها التسريح بدون مهلة العطلة وبدون علاوات، الأفعال الأتية:...- إذا شارك في توقف جماعي ونتاوري عن العمل خرقا الأحكام التشريعية الجاري العمل بها في هذا فئ المجال".

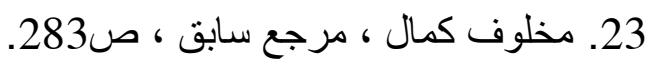

24. قرار المحكمة العليا، الغرفة الإجتماعية، رقم رهابع 400552 المؤرخ في 2008/04/09، مجلة المحكمة العليا 2008، العدد 02 ، ص 25. رعد سامي التميمي، العولمة والتتمية البشرية في الوطن العربي، دار دجلة،

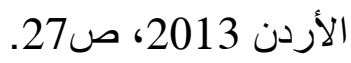

26. مأموني فاطمة الزهراء، تأثثر العولمة على قانون العمل الجزائري ، دكتور اهاه

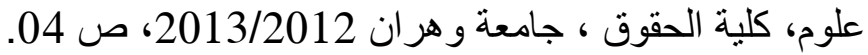
27. ر عد سامي التميمي، مرجع سابق، ص 28.

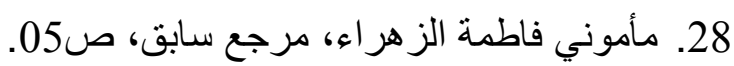

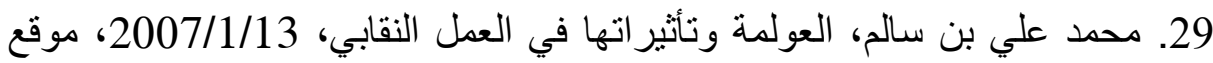

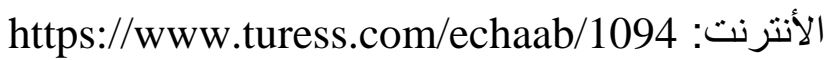
30. حيث نصت المادة 12 من القانون 11/90 المعدلة والمتممة على أنه:" يمكن ابرام عقد العمل لمدّة محدودة بالتوقيت الكامل أو التوقيت الجزئي في الحالات المنصوص عليها صر احة أدناه:

- عندما يوظف العامل لتنفيذ عمل مرتبط بعقود أشغال أو خدمات غير

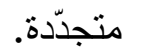

- عندما يتعلّق الأمر باستخلاف عامل مثبت في منصب تغيب عنه مؤقتا، ويجب على المستخدم أن يحتفظ بمنصب العمل لصاحبه. - عندما بتطلب الأمر من الهيئة المستخدمة اجراء أثنال دورية ذات طابع متقطع.

$$
\text { - عندما يبرر ذللك تز ايد العمل أو أسباب موسمية. }
$$
- عندما يتعلق الأمر بنشاطات أو أشنال ذات مدة محدودة أو مؤقتة بحكم طبيعتها". 31. ونشير هنا الى أن الخوصصة مصطلح ظهر في قاموس "webstar" عام 1983، ترجمة للكلمة الانجليزية " privatize" وعن الفرنسية " privatisation

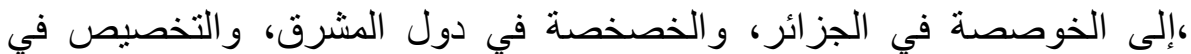
تونس، وتعرف بأنها التحول من القطاع العام الى القطاع الخاص أو أو تحويل الملكية

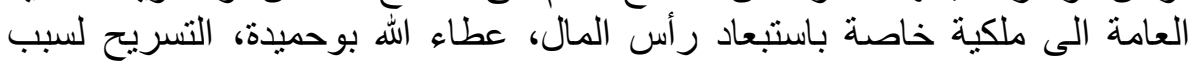

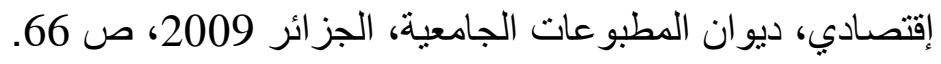

32. مفتشية العمل هي هيئة إدارية عمومية خولها المشرع مهام وصلاحيات عديدة في مجال التفتيش والتحقيق والرقابة على مدى تطبيق الأحكام التشريعية والتنظيمية و الاتفاقية الخاصة بالعمل ومساعدة العمال و المستخدمين وتقديم الإرشادات لهم كما لإنا 
خولها مهام التسوية والمصالحة في مجال منازعات العمل الجماعية.

33. الثركات الأجنبية بالجزائر تاكل عرق الجزائريين وتستعبدهم، 27 جويلية

2013، موقع الأنترنت: www.elmakam.com/?p=11100

34. بن حمزة حورية، العولمة والنقابية، موقع الأنترنت:

http://www.alnoor.se/article.asp?id=1081

35. بيان بشأن العولمة وأثرها على التمتع بالحقوق الاقتصادية والاجتماعية و الثقافية

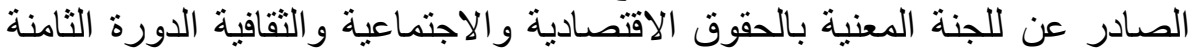
عشرة 1998، وتجدر الاشارة هنا الى أن هذه اللجنة مكلفة بمراقبة تنفيذ العهد الدولي الخاص بالحقوق الاقتصادية و الاجنماعية و الثقافية. 36. النقابات العمالية، موقع الأنترنت: www .djelfa.info 37. محمد علي بن سالم ، موقع الأنترنت السابق.

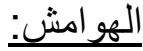

(1)- الإضراب في مصر، تقرير المنظمة المصرية حول الاضرابات و الاعتصامات،

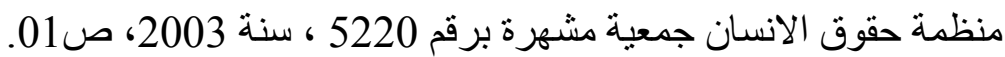

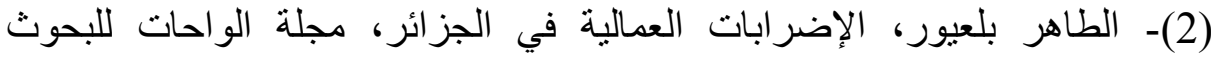

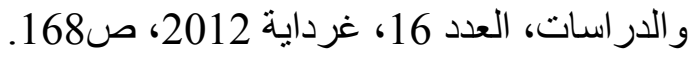

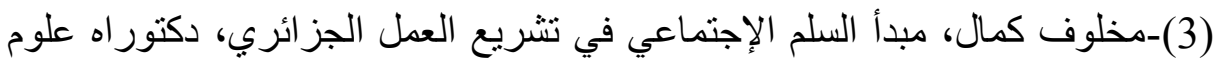

كلية الحقوق والعلوم السياسية، جامعة مولود معمري ، تيزي وزو 2014 ، ص06.

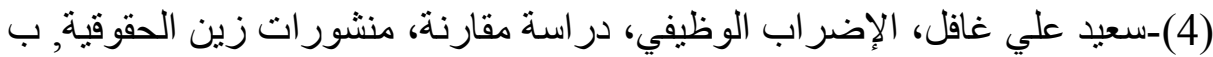

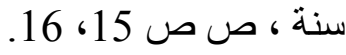

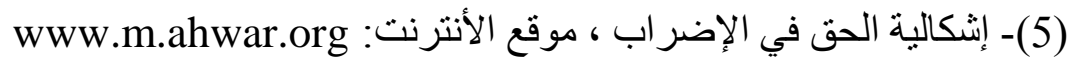

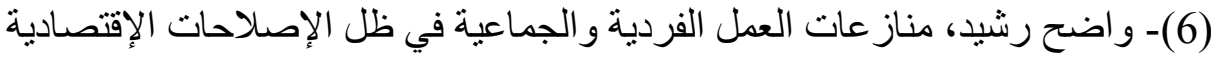

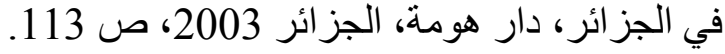

(7)- أحمية سليمان، الوجيز في قانون عليز علاقات العمل في التشريع الجزائري، ديوان

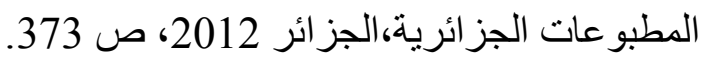

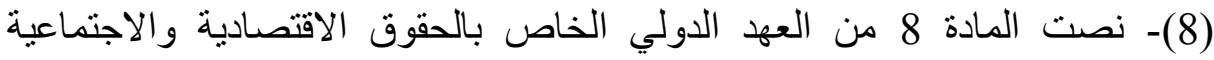

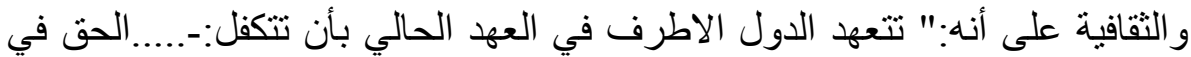

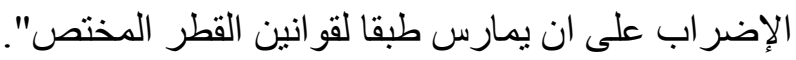

(9)-المادة 24 من قانون 02/90 التي جاء فيها أنه: " اذا استمر الخلاف بعد استنفاذ أعاذ

إجراءات المصالحة و الوساطة المنصوص عليها أعلاه، وفي غياب طرق فأ أخرى

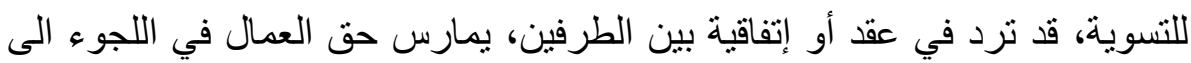
الإضر اب وفقا للثروط و الكيفيات المحددة في أحكام هذا القانون".

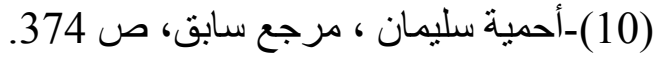

(11)- بشير هدفي، الوجيز في شرح قانون العمل، جسور للنشر والتوزيع، الطبعة 


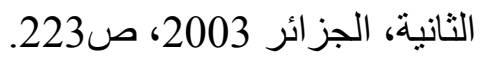

(12)-Amoura Amar, Droit du travaille et Droit sociale guide pratique, édition el maarifa, Alger 2002, p 2001.

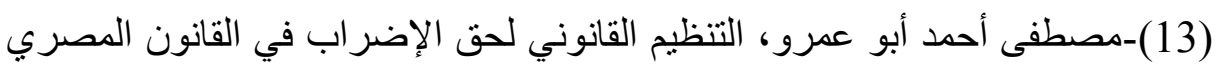

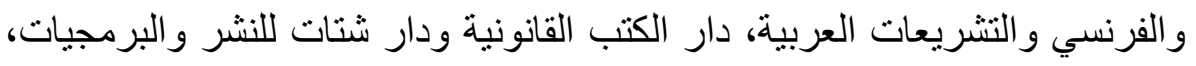

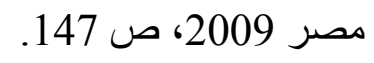

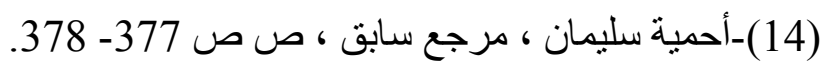

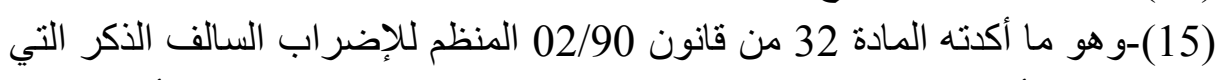

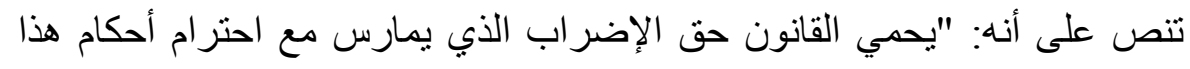

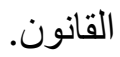

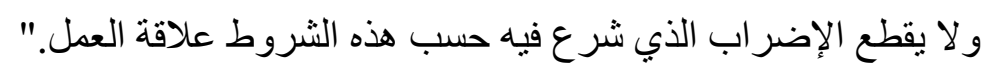

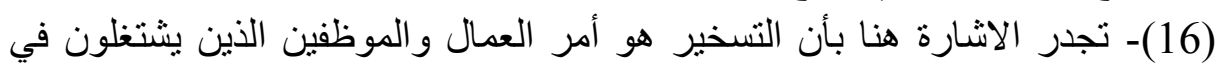

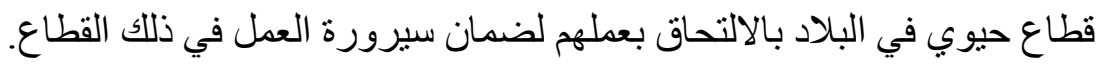
(17)- المادة 33 من القانون 02/90 السابق الذكر.

(18)- أمال بطاهر، النظام القانوني لحماية الأجور في القانون الجزائري، دار الجامعة

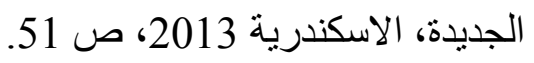

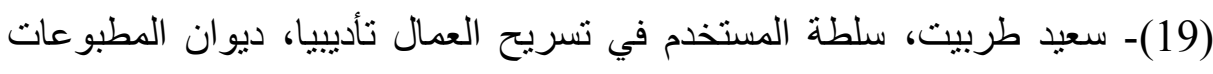

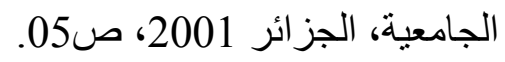

(20)-Mohamed Nasser Eddine Koriche, tome 01, Droit du travail , office des publications universitaires, Alger 2009,p193.

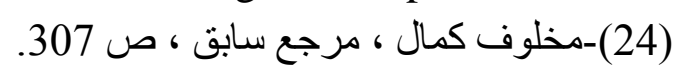

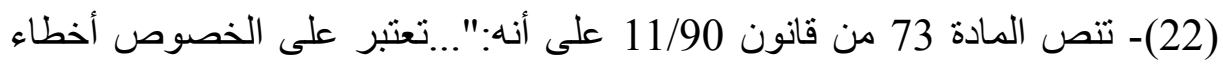

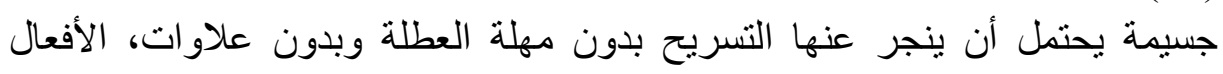

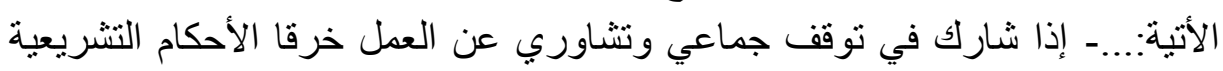

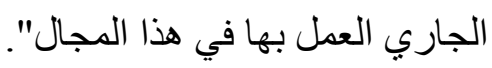

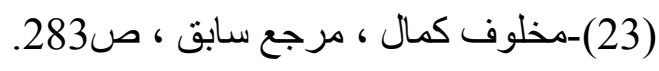

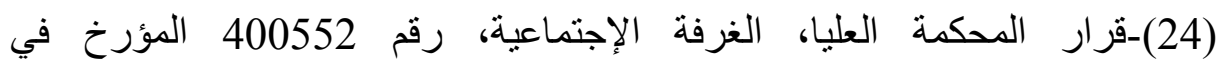

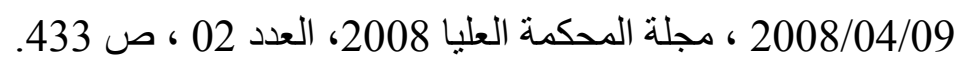

(25)- رعد سامي التميمي، العولمة و التنمية البشرية في الوطن العربية العربي، دار دجلة ،

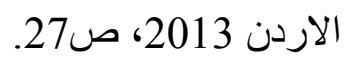

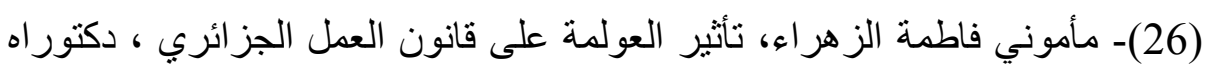

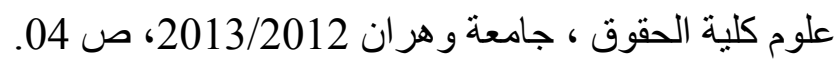

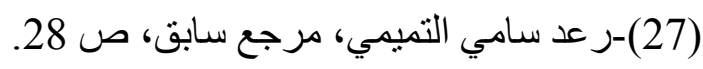

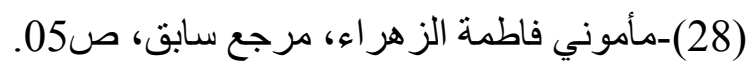

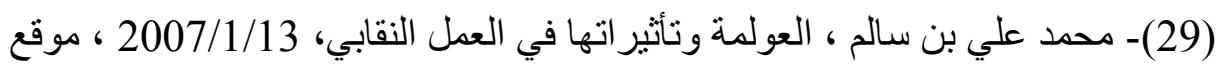


https://www.turess.com/echaab/1094

(30)- حيث نصت المادة 12 من القانون 11/90 المعدلة والمتممة على أنه:" يمكن ابرام عقد العمل لمدّة محدودة بالتوقيت الكامل أو التوقيت الجزئي في الحالات المنصوص عليها صر احة أدناه:

ــندما يوظف العامل لتنفيذ عمل مرتبط بعقود أشغال أو خدمات غير متجدّدة. ـ عندما يتعلّق الأمر باستخلاف عامل مثبت في منصب تغيب عنه مؤقتا، ويجب على على مئل المستخدم أن يحتفظ بمنصب العمل لصناحبه. ـعندما يتطلب الأمر من الهيئة المستخدمة اجر اء أشغال دورية ذات طابع متقطع. ـ عندما يبرر ذللك تز ايد العمل أو أسباب موسمية.

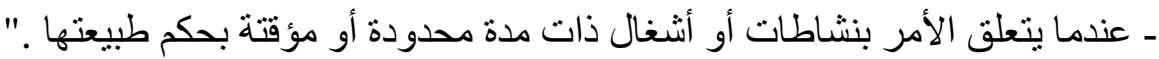

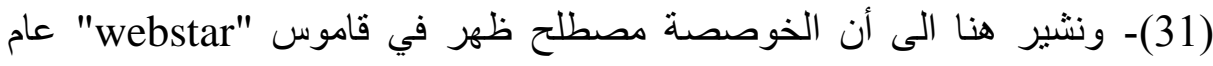

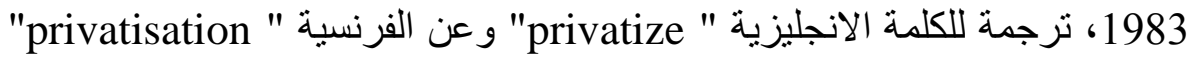
،الى الخوصصة في الجزائر، و الخصخصة في دول المشرق، و التخصيص في في تونس

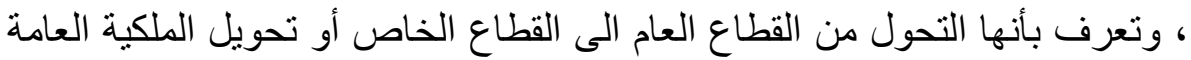

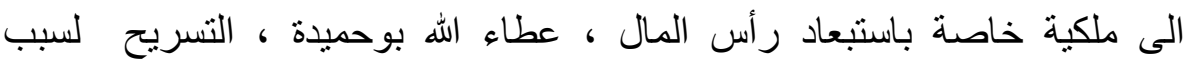

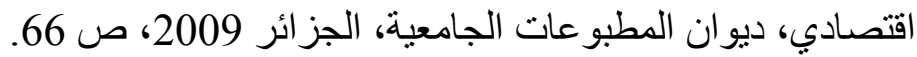

(32)-مفتشية العمل هي هيئة إدارية عمومية خولها المشرع مهام وصلاحيات عديدة في مجال التفتيش و التحقيق والرقابة على مدى تطبيق الأحكام التشريعية والتنظيمية التهية

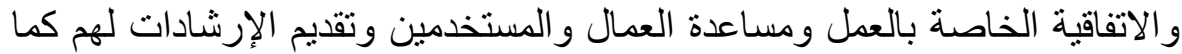

خولها مهام التسوية و المصالحة في مجال مناز عات العمل الجماعية. (33)- الثركات الأجنبية بالجزائر ناكل عرق الجزائريين وتستعبدهم، 27 جويلية 2013، موقع الأنترنت: www.elmakam.com/?p=11100. (34)- بن حمزة حورية، العولمة والنقابية، موقع الأنترنت: http://www.alnoor.se/article.asp?id=10818

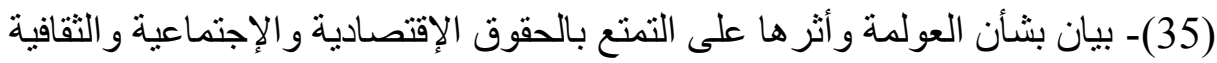

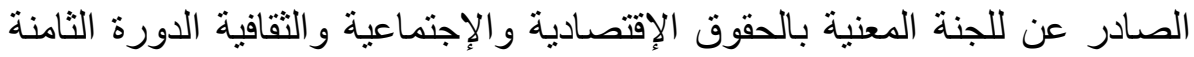
عشرة 1998، وتجدر الإشارة هنا الى أن هذه اللجنة مكلفة بمر اقبة تنفيذ العهد الدولي والإي الخاص بالحقوق الإقتصادية و الإجتماعية و الثقافية.

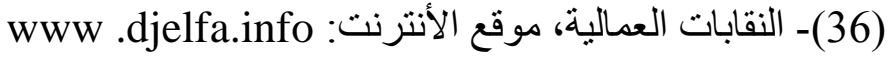
(37)- محمد علي بن سالم ، موقع الأنترنت السابق. مونع النترن. 